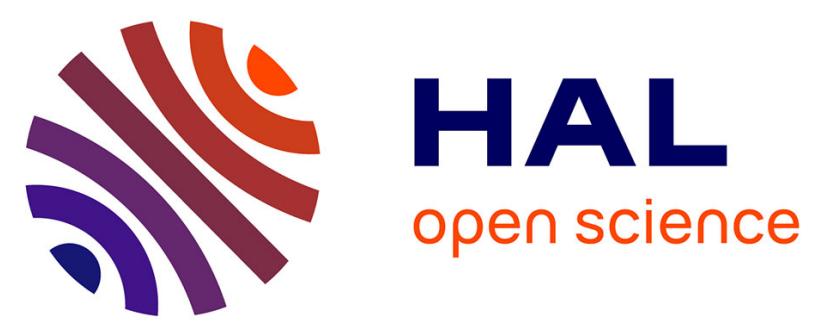

\title{
Series of Mn Complexes Based on N-Centered Ligands and Superoxide - Reactivity in an Anhydrous Medium and SOD-Like Activity in an Aqueous Medium Correlated to MnII/MnIII Redox Potentials
}

Stéphanie Durot, Clotilde Policar, Federico Cisnetti, François Lambert, Jean-Philippe Renault, Giorgio Pelosi, Guillaume Blain, Hafsa

Korri-Youssoufi, Jean-Pierre Mahy

\section{- To cite this version:}

Stéphanie Durot, Clotilde Policar, Federico Cisnetti, François Lambert, Jean-Philippe Renault, et al.. Series of Mn Complexes Based on N-Centered Ligands and Superoxide - Reactivity in an Anhydrous Medium and SOD-Like Activity in an Aqueous Medium Correlated to MnII/MnIII Redox Potentials. European Journal of Inorganic Chemistry, 2005, 2005 (17), pp.3513-3523. 10.1002/ejic.200400835 . hal-02011965

\section{HAL Id: hal-02011965 \\ https://hal.science/hal-02011965}

Submitted on 29 Apr 2020

HAL is a multi-disciplinary open access archive for the deposit and dissemination of scientific research documents, whether they are published or not. The documents may come from teaching and research institutions in France or abroad, or from public or private research centers.
L'archive ouverte pluridisciplinaire HAL, est destinée au dépôt et à la diffusion de documents scientifiques de niveau recherche, publiés ou non, émanant des établissements d'enseignement et de recherche français ou étrangers, des laboratoires publics ou privés. 


\title{
Series of Mn Complexes Based on $\mathrm{N}$-Centered Ligands and Superoxide - Reactivity in an Anhydrous Medium and SOD-Like Activity in an Aqueous Medium Correlated to $\mathrm{Mn}^{\mathrm{II}} / \mathrm{Mn}^{\mathrm{III}}$ Redox Potentials ${ }^{\mathrm{l}+\mathrm{II}+\neq 1}$
}

\author{
Stéphanie Durot, ${ }^{\text {|all }+*+1}$ Clotilde Policar, ${ }^{*|a| l+\neq l}$ Federico Cisnetti, ${ }^{\text {|al }}$ François Lambert, ${ }^{\text {|a| }}$ \\ Jean-Philippe Renault, ${ }^{|c|}$ Giorgio Pelosi,${ }^{|b|}$ Guillaume Blain, ${ }^{|\mathrm{d}|}$ Hafsa Korri-Youssoufi, ${ }^{|\mathrm{a}|}$ and \\ Jean-Pierre Mahylal
}

Keywords: N,O ligands / Manganese / Superoxide / SOD mimics / Imidazole / Phenolate

Two crystal structures are described in this article: (a) the structure of a monomeric $\mathrm{Mn}^{\mathrm{II}}$ complex with the tridentate $\mathrm{N}$ centered $\mathrm{N}_{3}$ ligand tris[(1-methyl-2-imidazolyl)methyl]amine (TMIMA) ([Mn $\left.\left.{ }^{\mathrm{II}}(\mathrm{TMIMA})_{2}\right]^{2+}\right)$; and (b) the structure of a monomeric $\mathrm{Mn}^{\mathrm{III}}$ complex with the tridentate $N$-centered $\mathrm{N}_{2} \mathrm{O}$ ligand 2-\{[(1-methyl-2-imidazolyl)methyl]amino\}phenolate $\left(\mathrm{PI}^{-}\right)^{|2|}\left(\left[\mathrm{Mn}^{\mathrm{III}}(\mathrm{PI})_{2}\right]^{+}\right)(5)$. The latter was isolated both in the $\mathrm{Mn}^{\mathrm{II}}$ and in the $\mathrm{Mn}^{\mathrm{III}}$ state, although only $\mathrm{Mn}^{\mathrm{III}}$ crystals were successfully grown. They are part of a series of Mn complexes prepared as SOD mimics, namely $\left[\mathrm{Mn}(\mathrm{BMPG})\left(\mathrm{H}_{2} \mathrm{O}\right)\right]^{+}$ (2) $\{\mathrm{BMPG}=\mathrm{N}, \mathrm{N}$-bis $[(6$-methyl-2-pyridyl $)$ methyl $]$ glycinate $\}$, $[\mathrm{Mn}(\mathrm{IPG})(\mathrm{MeOH})]^{+}$(3) $\{\mathrm{IPG}=N-[(1$-methyl-2-imidazolyl $)$ methyl]- $N$-(2-pyridylmethyl)glycinate], [Mn(BIG) $\left.\left(\mathrm{H}_{2} \mathrm{O}\right)_{2}\right]^{+}(\mathbf{4})$ $\{\mathrm{BIG}=\mathrm{N}, \mathrm{N}$-bis $[(1$-methyl-2-imidazolyl $)$ methyl $]$ glycinate $\}$. The reactivity of $\mathrm{Mn}^{\mathrm{II}}$ complexes $\mathbf{1}$ and $\mathbf{2}$ in an anhydrous medium is described and compared to that of complexes 3 and 4 , the data for which was previously published. The cyclic voltammograms of the whole complex series were recorded in an aqueous medium (collidine buffer). Their SODlike activities were estimated by the McCord-Fridovich test (IC50 with $22 \mu \mathrm{M}$ cytc $\mathrm{Fe}^{\mathrm{mI}}$ : $1.6 \pm 0.1 \mu \mathrm{MolL}^{-1}$ for 1, $1.2 \pm 0.5 \mu \mathrm{molL}^{-1}$ for $2,3.0 \pm 0.2 \mu \mathrm{molL}^{-1}$ for $3,3.7 \pm 0.6 \mu \mathrm{molL}^{-1}$ for $4,0.8 \pm 0.1 \mu \mathrm{mol} \mathrm{L}^{-1}$ for 5 ). IC50 values were converted into the corresponding kinetic constant $k_{\mathrm{McCF}}$ values. A linear correlation between $E_{\mathrm{a}}$ and $\log \left(k_{\mathrm{McCF}}\right)$ was obtained, indicating that in this series the conversion to $\mathrm{Mn}^{\mathrm{III}}$ is probably the rate-limiting step. This is of substantial importance for further Mn-SOD mimic design in this series.

\section{Introduction}

Superoxide $\left(\mathrm{O}_{2}^{-}{ }^{-}\right)$, as the first species in the dioxygen reduction cascade, is a toxic species involved in oxidative stress ${ }^{[3-5]}$ Its concentration is controlled in vivo by superoxide dismutases, metalloenzymes that catalyze its dismutation. Superoxide is considered to be responsible for several pathological situations. There is a pharmaceutical requirement for molecules that could scavenge or, even bet-

Part 2 of a series. Part 1: Ref. ${ }^{[1]}$

[\$+] Abbreviations: Ref. ${ }^{[2]}$

[a] Laboratoire de Chimie Bio-organique et Bio-inorganique, UMR8124, Bâtiment 420, Université Paris XI,

91405 Orsay Cedex, France

Fax: +33-1-69157231

E-mail: cpolicar@icmo.u-psud.fr

[b] Dipartimento di Chimica Generale ed Inorganica, Chimica

Analitica, Chimica Fisica, Università di Parma,

Parco Area delle Scienze 17A, 43100 Parma, Italy

[c] Laboratoire de Radiolyse CEA Saclay (DSM/DRECAM/ SCM-URA331),

91405 Orsay Cedex, France

[d] Laboratoire de Chimie Inorganique, UMR8613, Bâtiment 420, Université Paris XI,

91405 Orsay Cedex, France

$[+*]$ These two authors contributed equally to this work. ter, catalytically dismutate superoxide. ${ }^{[6-8]}$ The design of low molecular weight complex SOD mimics requires greater understanding of the effect of the metal environment on the SOD-like activity. In the field of superoxide dismutase mimics, copper, iron, manganese and cobalt complexes have been described. ${ }^{[7-12]} \mathrm{Mn}$ is the least toxic of these metal ions. ${ }^{[8]}$ In our laboratory, we design Mn complexes and test them as SOD mimics. In this article, the crystal structure of a monomeric $\mathrm{Mn}^{\mathrm{II}}$ complex (1) derived from $\mathrm{L}^{1}\{\operatorname{tris}[(1-$ methyl-2-imidazolyl)methyl]amine or TMIMA $\}$ is presented $\left\{\left[\mathrm{Mn}^{\mathrm{II}}(\mathrm{TMIMA})_{2}\right]\left(\mathrm{PF}_{6}\right)_{2}\right\}$. The crystal structure of a monomeric $\mathrm{Mn}^{\mathrm{III}}$ complex derived from $\mathbf{L}^{2}(2-\{[(1-$ methyl-2-imidazolyl)methyl]amino phenolate or $\left.\mathrm{PI}^{-}\right)$is also described $\left\{\left[\mathrm{Mn}^{\mathrm{III}}(\mathrm{PI})_{2}\right]\left(\mathrm{PF}_{6}\right)\right\}$. In the latter case, both $\mathrm{Mn}^{\mathrm{II}}$ $\left(5^{\prime}\right)$ and $\mathrm{Mn}^{\text {III }}$ states (5) could be isolated, although only $\mathrm{Mn}^{\mathrm{III}}$ crystals were successfully obtained. Complexes 1 and $\mathbf{5}$ are part of a series of $\mathrm{Mn}$ complexes prepared as SOD mimics, previously published, namely $\left[\mathrm{Mn}(\mathrm{BMPG})\left(\mathrm{H}_{2} \mathrm{O}\right)\right]^{+}$ (2) $\{\mathrm{BMPG}=N, N$-bis $[(6-$ methyl-2-pyridyl $)$ methyl $]$ glycinate $\},{ }^{[13]}[\mathrm{Mn}(\mathrm{IPG})(\mathrm{MeOH})]^{+}$(3) $\{\mathrm{IPG}=N-[(1-$ methyl-2-imidazolyl)methyl]- $N$-(2-pyridylmethyl)glycinate \}, $\left[\mathrm{Mn}(\mathrm{BIG})\left(\mathrm{H}_{2} \mathrm{O}\right)_{2}\right]^{+}$(4) $\{\mathrm{BIG}=N, N$-bis[(1-methyl-2-imidazolyl)methyl]glycinate [" $^{[1]} \mathrm{A}$ general approach to reaction with superoxide has already been published. ${ }^{[1]}$ Firstly, this 
article consists of a study of the reactivity of $\mathrm{Mn}^{\mathrm{II}}$ complexes with superoxide in an anhydrous medium (DMSO). Secondly, the reactivity in an aqueous solution is evaluated with the conventional McCord-Fridovich assay and/or pulse radiolysis. Presented is a brief study of the $\mathrm{Mn}^{\mathrm{II}}$ complexes (1 and 2) in the anhydrous medium and an evaluation of the SOD activity of complexes 1, 2, and $\mathbf{5}$ with the McCord-Fridovich assay. These activities are presented here in terms of a recalculated kinetic constant, $k_{\mathrm{McCF}}$. For two of the complexes, namely, $\mathbf{3}$ and $\mathbf{4}, k_{\mathrm{McCF}}$ values are compared with the kinetic constants measured by pulse radiolysis. For the whole series the relationship between redox potential and $k_{\mathrm{McCF}}$ has been investigated.

\section{Results}

\section{Syntheses}

\section{Ligand Synthesis}

The synthesis of the $\mathbf{L}^{1}$ ligand is already known. ${ }^{[14,15]} \mathrm{A}$ new synthetic pathway is presented in the Exp. Sect., involving an amine tertiarization by reductive amination instead of a nucleophilic substitution. The new method displayed a higher yield $(90 \%$ vs. $62 \%$ from bis[2-(1-methyl-2-imidazolyl)methyl]amine.

Ligand $\mathbf{L}^{\mathbf{5}}$ was synthesized as shown in Scheme 1 by a two-step synthesis. The yield was moderate but the procedure was very easy. 2-(Methylamino)phenol was obtained by catalytic hydrogenation $(\mathrm{Ni})$ of 2-cyanophenol. It was reductively coupled to $\mathrm{N}$-methyl-2-imidazolcarboxaldehyde obtained according to a published procedure. ${ }^{[16]}$

\section{Preparation of the Complexes}

$\mathrm{Mn}^{11}$ complex 1 was obtained from $\mathbf{L}^{1}$ (see Figure 1) with $\mathrm{PF}_{6}{ }^{-}$as the counter-anion in $\mathrm{MeOH} / \mathrm{H}_{2} \mathrm{O}(1: 1)$. X-ray suitable crystals were successfully grown providing the monomeric $\left[\mathrm{Mn}^{\mathrm{II}}(\mathrm{TMIMA})_{2}\right]\left(\mathrm{PF}_{6}\right)_{2}$ compound 1. Experimental details are described in the Exp. Sect.

$\mathrm{Mn}^{\mathrm{II}}$ complex $\mathbf{5}^{\prime}$ was obtained from $\mathbf{L}^{\mathbf{5}}$ (see Figure 1) under strictly controlled anaerobic conditions. A white precipitate was obtained, but no crystal has been successfully grown so far. The powder could be recrystallized from $\mathrm{CH}_{3} \mathrm{CN}$ by diffusion of $t$ BuOMe as $\left[\mathrm{Mn}^{\mathrm{III}}(\mathrm{PI})_{2}\right]-$ $\left(\mathrm{PF}_{6}\right)\left(\mathrm{CH}_{3} \mathrm{CN}\right)$. When the synthesis was carried out in the

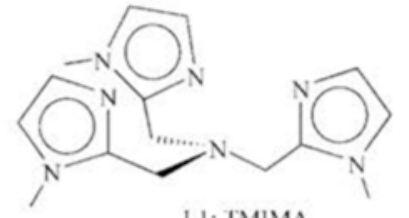

LI: TMIMA

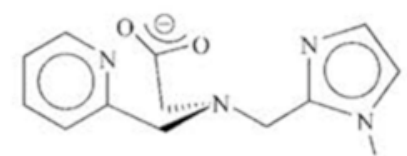

I.3: IPG

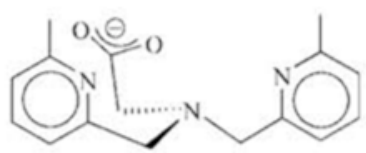

L2: BMPG

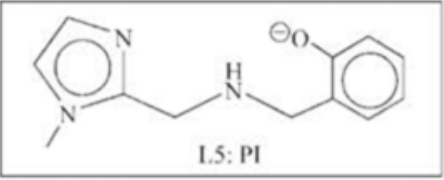

Figure 1. Structure of the ligands.

presence of dioxygen, a dark violet precipitate of an $\mathrm{Mn}^{\mathrm{III}}$ complex (5) was directly obtained.

\section{Description of the Structure of $\left[\mathrm{Mn}(\mathrm{TMIMA})_{2} \mid\left(\mathrm{PF}_{6}\right)_{2}(1)\right.$}

An X-ray diffraction study was carried out on the [Mn(TMIMA $\left.)_{2}\right]\left(\mathrm{PF}_{6}\right)_{2}$ complex 1 and the experimental details are reported in Table 6 (Exp. Sect.). The asymmetric unit consists of a cationic moiety, formed by two neutral tridentate ligands coordinated to a central $\mathrm{Mn}^{\mathrm{II}}$ ion, lying on a center of symmetry, and two hexafluorophosphate anions (see Figure 2). Selected distances and angles are reported in Table 1.

The hexafluorophosphate anions are found in two positions with an occupancy of 0.5 . The manganese(II) ion is coordinated to six imidazole nitrogen atoms with distances of 2.364(2), 2.366(3), and 2.307(2) $\AA$ (by symmetry, the other $\mathrm{Mn}-\mathrm{N}$ distances are identical). These distances are larger than the average value found using the Cambridge Crystallographic Database (CCDC) ${ }^{[17]}$ for manganese complexes with ligands containing the imidazole ring [av. 2.226(12) $\AA$ on the basis of 42 fragments; see the list in the Supporting information].

The $\mathrm{Mn}-\mathrm{N}_{\text {tripod }}$ distance is 2.916(2) $\AA$, which is longer than the sum of their van der Waals radii $(2.82 \AA)$. This is due both to the complete metal coordination sphere and to

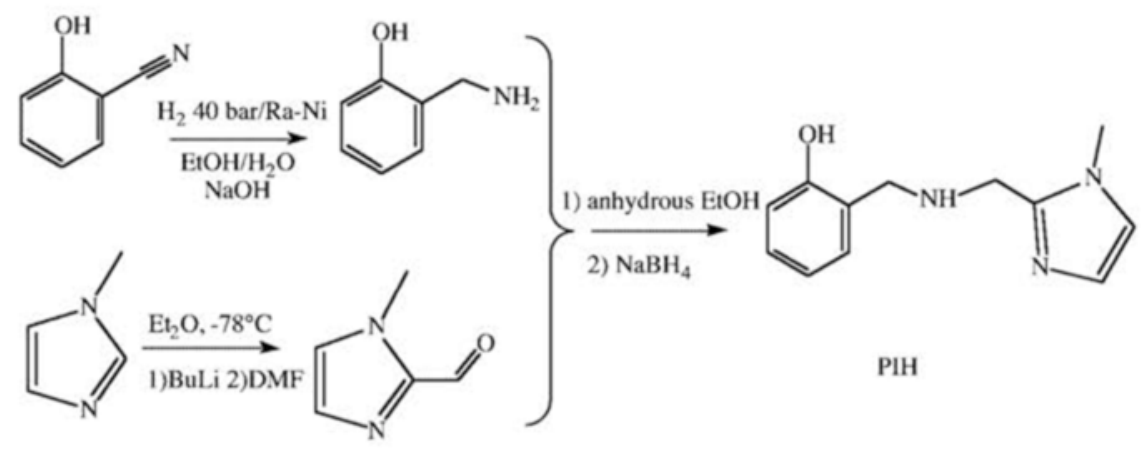

Scheme 1. Synthetic pathway to PIH. 


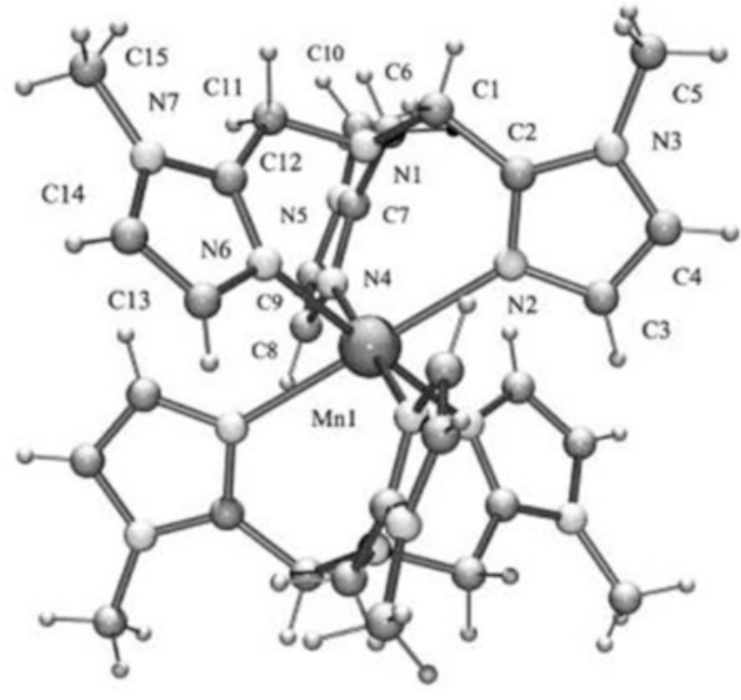

Figure 2. Representation of cationic complex 1.

Table 1. Selected bonds and angles (symmetry operator A: $1-x$, $-y, 1-z)$.

\begin{tabular}{lclc}
\hline Bonds & {$[\AA ̊]$} & Angles & {$\left[{ }^{\circ}\right]$} \\
\hline Mn1-N2 & $2.364(2)$ & N2-Mn1-N4 & $98.73(7)$ \\
Mn1-N4 & $2.307(2)$ & N2-Mn1-N6 & $99.91(8)$ \\
Mn1-N6 & $2.366(3)$ & N4-Mn1-N6 & $100.48(7)$ \\
Mn1-N2A & $2.364(2)$ & N2-Mn1-N4A & $81.28(7)$ \\
Mn1-N4A & $2.307(2)$ & N2-Mn1-N6A & $80.09(7)$ \\
Mn1-N6A & $2.366(3)$ & N4-Mn1-N6A & $79.52(7)$ \\
\hline
\end{tabular}

the steric constraints imposed by the presence of two bulky ligands. In comparable structures, with a single tripodal ligand and a monodentate donor that completes the octahedron, the tripodal nitrogen atom is much closer to the central ion and forms a coordination bond: the average distance in these cases is 2.53(4) $\AA$ (on the basis of the same 42 fragments listed in the Supporting information). Deviation from the octahedral structure is also noticeable in the angle values (see Table 1).

Sheets of complex molecules, interacting through van der Waals contacts, pile up running parallel to the $x z$ plane and are held together by a complex system of hydrogen bonds formed by the fluorine atoms of the hexafluorophosphate anions with the methyl and methylene groups of the ligand. The shortest distance between manganese ions is $\mathrm{Mn} \cdots \mathrm{Mn}$ $(x,-y-1 / 2,+z-1 / 2)$ and is 9.413(1) $\AA$. The magnetic properties of complex 1 are that of a Curie-law $\mathrm{Mn}^{\text {II }}$ ion, with a $\chi_{\text {mol }} T$ value of $4.4 \mathrm{~cm}^{3} \mathrm{~mol}^{-1} \mathrm{~K}$ from ambient temperature down to $2 \mathrm{~K}$ (results not shown), with no efficient $\mathrm{Mn}^{\mathrm{II}}$ $\mathrm{Mn}^{\mathrm{II}}$ intermolecular through-space interaction at such distances. ${ }^{[13]}$

\section{Description of the Structure of $\left[\mathrm{Mn}(\mathrm{PI})_{2}\right]\left(\mathrm{PF}_{6}\right)\left(\mathrm{CH}_{3} \mathrm{CN}\right)(5)$}

An X-ray diffraction study has been carried out on the complex $\left[\mathrm{Mn}(\mathrm{PI})_{2}\right]\left(\mathrm{PF}_{6}\right)\left(\mathrm{CH}_{3} \mathrm{CN}\right)$ (5). An ORTEP view of the manganese complex is shown in Figure 3 and the experimental details regarding data collection are reported in
Table 6 (Exp. Sect.). The structure consists of two cationic moieties made up of manganese atoms lying on centers of symmetry surrounded by two tridentate monoanionic ligands. Manganese(III) ions present a slightly distorted octahedral coordination geometry as can be seen from the coordination distances and angles (Table 2), with a compression along the $\mathrm{O}_{\text {phenolato }}-\mathrm{Mn}-\mathrm{O}_{\text {phenolato }}$

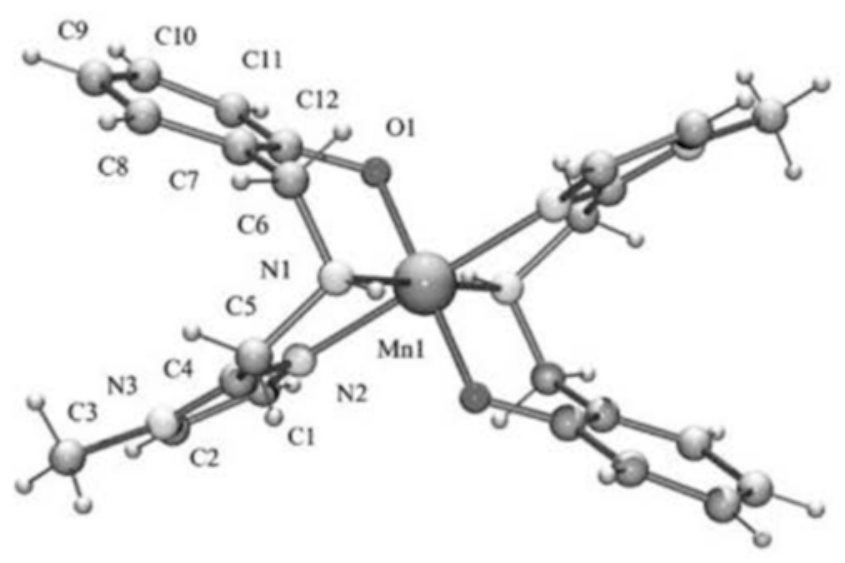

Figure 3. Representation of cationic complex $\mathbf{5}$.

Table 2. Selected distances and angles for $\mathbf{5}$.

\begin{tabular}{lclc}
\hline Distances & {$[\AA ̊]$} & Angles & {$\left[{ }^{\circ}\right]$} \\
\hline Mn1-O1 & $1.82(1)$ & O1-Mn1-N1 & $91.6(7)$ \\
Mn1-N1 & $2.20(2)$ & O1-Mn1-N2 & $92.3(7)$ \\
Mn1-N2 & $2.17(2)$ & N1-Mn1-N2 & $78.9(8)$ \\
Mn2-O2 & $1.85(1)$ & O2-Mn2-N4 & $91.7(6)$ \\
Mn2-N4 & $2.19(2)$ & O2-Mn2-N5 & $93.3(6)$ \\
Mn2-N5 & $2.18(2)$ & N4-Mn2-N5 & $79.0(7)$ \\
\hline
\end{tabular}

It is noteworthy that a hydrogen bond exists in the two independent molecules between the amino NH group and the phenol oxygen atom of the centrosymmetrically related

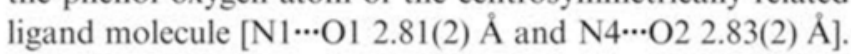
A hexafluorophosphate anion compensates the charge of the cationic complex. Hydrogen bonds between fluorine atoms of $\mathrm{PF}_{6}{ }^{-}$and $\mathrm{N} 1$ and $\mathrm{N} 4$ are responsible for the overall packing. The structure also contains an acetonitrile crystallization molecule that occupies the remaining interstices.

\section{Reactivity of the $\mathrm{Mn}^{\text {II }}$ Complexes with Superoxide in an Anhydrous Medium}

In the series $\mathbf{1}, \mathbf{2}, \mathbf{3}$, and $\mathbf{4}, \mathrm{Mn}^{\mathrm{II}}$ ions bear 0,1 or $2 \mathrm{H}_{2} \mathrm{O}$ molecules, and show different bulkiness around $\mathrm{Mn}$. The reactivity of both $\left[\mathrm{Mn}^{\mathrm{II}}(\mathrm{BMPG})\left(\mathrm{H}_{2} \mathrm{O}\right)\right]^{+}$(2) and $\left[\mathrm{Mn}^{\mathrm{II}}\right.$ $\left.(\text { TMIMA })_{2}\right]^{2+}(\mathbf{1})$ was studied as described previously in the case of both 3 and $\mathbf{4}^{[1]}$

Successive amounts of superoxide were added to a $10^{-3} \mathrm{~mol} \mathrm{~L}^{-1}$ solution of the complex in anhydrous DMSO. EPR spectra were recorded at $10 \mathrm{~K}$. For 2 , the initial $\mathrm{Mn}^{\mathrm{II}}$ signal $^{[18]}$ decreased from 0 to 1.5 equiv. superoxide. From 1.5 to 3 equiv., the solution was EPR-silent; and above 
Table 3. Reactivity of superoxide in anhydrous DMSO with $\mathrm{Mn}^{\mathrm{II}}$ complexes from the $\mathrm{N}$-tripodal series: amount of superoxide consumed deduced from the EPR spectrum.

\begin{tabular}{lcccc}
\hline & $\mathrm{Mn}^{\mathrm{II}}(\mathrm{TMIMA})_{2}{ }^{2+}$ & $\mathrm{Mn}^{\mathrm{II}}(\mathrm{IPG})(\mathrm{MeOH})^{+}$ & $\mathrm{Mn}^{\mathrm{II}}(\mathrm{BMPG})\left(\mathrm{H}_{2} \mathrm{O}\right)^{+}$ & $\mathrm{Mn}^{\mathrm{II}}(\mathrm{BIG})\left(\mathrm{H}_{2} \mathrm{O}\right)_{2}{ }^{+}$ \\
\hline $\begin{array}{l}\text { Number of water bound to } \\
\mathrm{Mn}\end{array}$ & 0 & 0 & 1 & 2 \\
$\mathrm{O}_{2}^{-}$consumed (equiv./Mn $\left.{ }^{-1}\right)$ & I equiv. & 1 equiv. & 3 equiv. & $>5$ equiv. \\
\hline
\end{tabular}

4 equiv., a signal from superoxide was finally obtained and quantified (data not shown, see Exp. Sect. and Table 3). For 1, the 6-line hyperfine signal from $\mathrm{Mn}^{\mathrm{II}}$ decreased upon superoxide addition; and at 2 equiv., the superoxide EPR signal was recovered and quantified (see Exp. Sect., Table 3 and Figure 4).

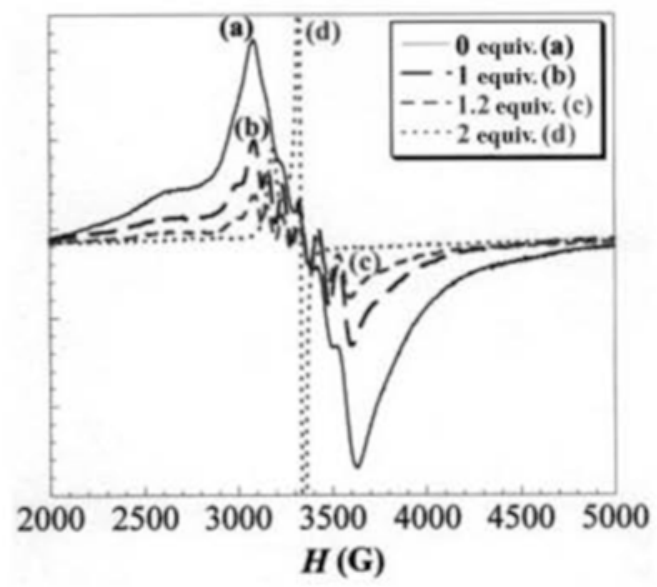

Figure 4. Reactivity of $\left[\mathrm{Mn}(\mathrm{TMIMA})_{2}\right]^{2+}$ (1) with superoxide in anhydrous DMSO. [Mn(TMIMA $\left.)_{2}\right]\left(\mathrm{PF}_{6}\right)_{2}\left(10^{-3} \mathrm{~mol} \mathrm{~L}^{-1}\right), 100 \mathrm{~K}, v$ $=9.38 \mathrm{GHz}$, att. $20 \mathrm{~dB}$, mod. amp. $5 \mathrm{G}, t_{\mathrm{c}}=41 \mathrm{~ms}$.

These results show that both $\mathbf{1}$ and $\mathbf{2}$ react with superoxide. No multiline signal was observed, showing that the formation of $\mathrm{Mn}^{\mathrm{III}} \mathrm{Mn}^{\mathrm{IV}}$ di- $\mu$-oxo dimers, previously observed with $\mathbf{3}$ and $\mathbf{4},{ }^{[1,19]}$ was not obtained in the case of $\mathbf{1}$ and $\mathbf{2}$. This can be tentatively assigned to the steric crowding due the methyl groups in $\mathbf{2}$ and to the complete coordination sphere in $\mathbf{1}$.
The superoxide signal was recovered at a different $\mathrm{O}_{2}-/$ Mn stoichiometry for these complexes and quantified. The amount of $\mathrm{O}_{2}^{-}$consumed was determined (see Table 3). It appears that the more water molecules are coordinated to the $\mathrm{Mn}^{\text {II }}$, the more equivalents of superoxide are consumed. The presence of the Mn ion is necessary since water alone, at the same concentration and under the same experimental conditions, did not switch off the superoxide signal.

\section{Tuning Redox Potentials to Tune the SOD-Like Activity}

\section{Redox Potential and SOD Activity}

The catalysis of the superoxide dismutation is a redox process, involving both $\mathrm{Mn}^{\mathrm{II}}$ and $\mathrm{Mn}^{\mathrm{III}}$ oxidation states. To make this redox catalysis efficient, the redox potential of the $\mathrm{Mn}^{\mathrm{III}} / \mathrm{Mn}^{\mathrm{II}}$ couple should be, as encountered in SODs, ${ }^{[20]}$ between the potential of the two couples $\mathrm{O}_{2} / \mathrm{O}_{2}{ }^{--}$and $\mathrm{O}_{2}{ }^{-}-$ $\mathrm{H}_{2} \mathrm{O}_{2}$-that is, at $\mathrm{pH}=7,-0.40 \mathrm{~V}$ and $+0.65 \mathrm{~V} / \mathrm{SCE}$, respectively (see Figure 5). ${ }^{[9,21-24]}$ Theoretically, the closer the potential of the two couples, the faster the reaction between them. Hitherto, the value optimizing the kinetics of both oxidation and reduction is the midway potential, i.e. $0.12 \mathrm{~V} /$ SCE. $[9,20]$

The $\mathrm{Mn}^{\mathrm{III}} / \mathrm{Mn}^{\mathrm{II}}$ redox potential is controlled by the coordination sphere around the metal center, either through the nature of the Lewis bases coordinated to the Mn center, by electronic effect on the Lewis bases, ${ }^{[25]}$ or by the geometry around the $\mathrm{Mn}$ center. Increasing the number of the $\mathrm{O}^{-}$ donor will lower the potential by increasing the electron density onto the metal center. $\mathrm{Mn}^{\mathrm{III}}$, as a $\mathrm{d}^{4}$ ion, will prefer a geometric distortion from the octahedric structure. The redox potential of the $\mathrm{Mn}^{\mathrm{III}} / \mathrm{Mn}^{\mathrm{II}}$ couple can be lowered by

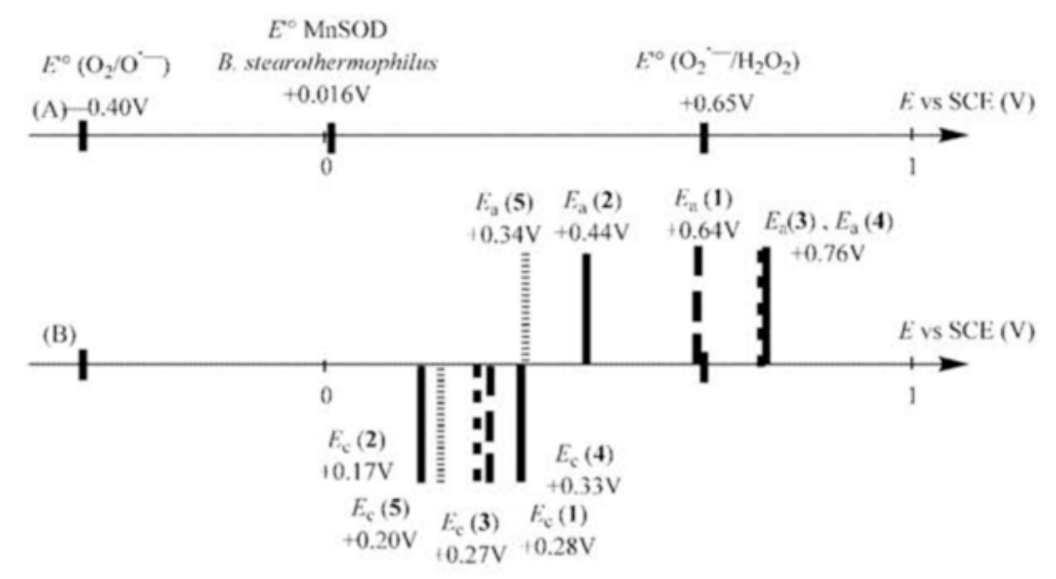

Figure 5. (A) Apparent standard redox potential for superoxide couples at $\mathrm{pH}=7$. (B) Anodic and cathodic half-wave potentials for the complexes in collidine $\mathrm{pH} 7.5$ buffer. 
controlling the geometry around the metal center, that is by imposing some deformation with regards to the octahedral environment. ${ }^{[26]}$

No electrochemical wave was observed for the $\mathrm{Mn}^{\text {II }}$ complexes of this series in dimethyl sulfoxide, acetonitrile or phosphate buffer. This is not uncommon for $\mathrm{Mn}^{\mathrm{II}}$ complexes. ${ }^{[27-29]}$ In collidine buffer $(\mathrm{pH}=7.5)^{[30]}$ however, irreversible waves were recorded (see Figure 6 in the case of 4). Anodic and cathodic potentials (Table 4 and Figure 5) are within $(\mathbf{2}, \mathbf{5}$, and $\mathbf{1})$ or at the limit (3 and $\mathbf{4})$ of the required region for effective superoxide dismutation. Potentials for $\mathbf{3}$ and $\mathbf{4}$ are close, which is consistent with the similar environment around the metal cations. They are close to the potential previously reported for a $\mathrm{Mn}^{\mathrm{II}}$ coordinated with $N, N$-bis(2-pyridylmethyl)-(S)-histidine, which shows a similar coordination sphere ( 2 imidazoles, 1 pyridine, 1 carboxylate) ${ }^{[30]}$ For $\mathbf{1}$ and $\mathbf{2}$, the anodic wave potentials are less positive. The conversion of $\mathrm{Mn}^{\mathrm{II}}$ into $\mathrm{Mn}^{\mathrm{III}}$ is thus easier. This can be assigned to the steric crowding encountered in $\mathbf{1}$ and $\mathbf{2}$, which may favor a distorted environment around the metal center. In $\mathbf{5}$, the $\mathrm{N}_{4} \mathrm{O}_{2}$ environment favors the $\mathrm{Mn}^{\mathrm{III}}$ by comparison with the nitrogen-richer environment for the other complexes.

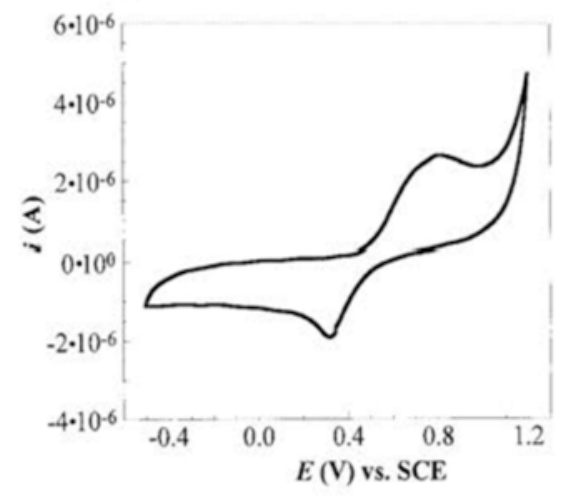

Figure 6. Voltammogram of $4\left[2 \times 10^{-3} \mathrm{~mol} \mathrm{~L}^{-1}\right.$ (on the basis of $\mathrm{Mn}$ content)], collidine buffer $(50 \mathrm{~mm}), \mathrm{pH}=7.5,100 \mathrm{mV} \mathrm{s}^{-1}$. Working electrode: vitrous carbon disk.

Table 4. Redox potential for the anodic and cathodic waves for complexes 1-5.

\begin{tabular}{cll}
\hline Complex & $E_{\mathrm{a}}^{[\mathrm{a}]}$ & $E_{\mathrm{c}}^{[\mathrm{a}]}$ \\
\hline $\mathbf{1}$ & 0.64 & 0.28 \\
$\mathbf{2}$ & 0.44 & 0.17 \\
$\mathbf{3}$ & 0.76 & 0.27 \\
$\mathbf{4}$ & 0.76 & 0.33 \\
$\mathbf{5}$ & 0.34 & 0.20 \\
\hline
\end{tabular}

[a] V vs. SCE.

\section{Evaluation of the SOD-Like Activity: McCord-Fridovich Assay}

Reactivity towards the superoxide was investigated in an aqueous phosphate buffer $(\mathrm{pH}=7.8)$ with the McCordFridovich assay, using the xanthine-xanthine oxidase system to produce the superoxide. The test is based on a kin- etic competition for superoxide reduction between the putative superoxide scavenger and ferricytochrome $\mathrm{c}^{[31]}$ The reduction of ferricytochrome $\mathrm{c}$ was monitored spectrophotometrically at $550 \mathrm{~nm}$. This test requires several preliminary checks in order to ensure its reliability (see Exp. Sect.). ${ }^{[1,8,32,33]}$

Complexes 1-5 inhibited the reduction of ferricytochrome c. The inhibition percentage was measured for several complex concentrations and the IC50 value was then deduced by two graphical methods (see Figure 7 and Exp. Sect. for details). ${ }^{[1,31,32,34,35]}$ They are reported in Table 5 ,
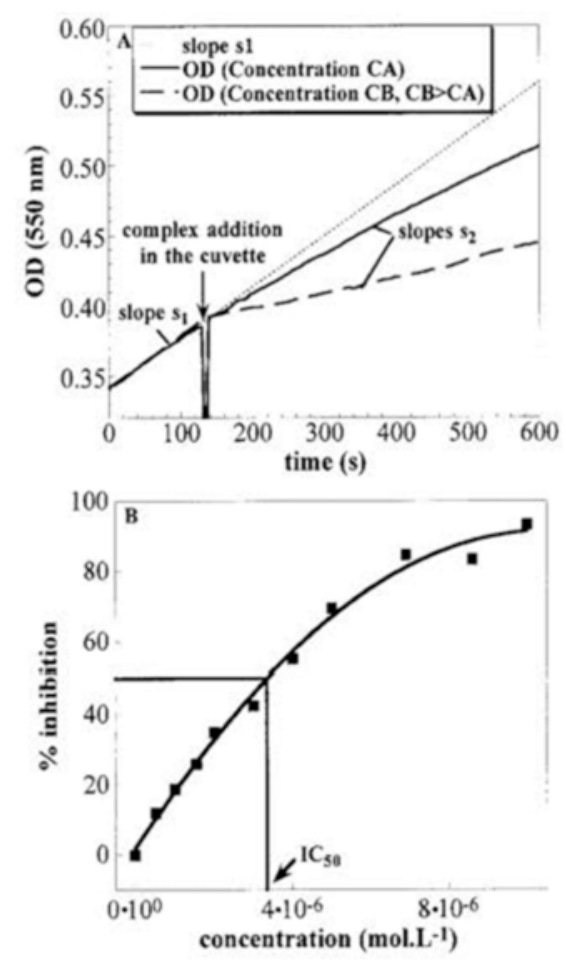

Figure 7. A. Kinetics of the reduction of ferricytochrome c $(550 \mathrm{~nm})$ without and with the putative SOD mimic 4. B. Inhibition percentage as a function of 4 : IC50 determination.

It should be noted that reported IC50 values are dependent both on the detector used [usually cytochrome $\mathrm{c} \mathrm{Fe}$ or nitroblue tetrazolium (NBT)] and on its concentration. For a given putative SOD mimic, the smaller the detector concentration, the smaller the IC50 value. Therefore, IC50 values are not appropriate for comparisons with the literature. From the measured $I C 50$ values, it is possible to calculate a kinetic constant value $\left(k_{\mathrm{McCF}}\right)$, which is independent of both detector concentration and nature. At the IC50 concentration, superoxide reacts at the same speed with the detector and the putative SOD mimic. Then, $k_{\mathrm{McCF}}=$ $k_{\text {detector }}$ [detector] $/ / C 50{ }^{[36]}$ In the case of cytochrome $\mathrm{c} \mathrm{Fe}{ }^{\mathrm{III}}$ as the detector, $k_{\text {Cytc }}\left(\mathrm{pH}=7.8 ; 21^{\circ} \mathrm{C}\right)=$ $2.6 \times 10^{5} \mathrm{~mol}^{-1} \mathrm{Ls}^{-1} \cdot{ }^{[37]}$ In the case of NBT, $k_{\mathrm{NBT}}(\mathrm{pH}=7.8)$ $=5.94 \times 10^{4} \mathrm{~mol}^{-1} \mathrm{Ls}^{-1} \cdot[38]$

Table 5 reports some values from the literature. The tested compounds 1-4 are within the range of the activities 
served rate constant had a value of $1.3 \times 10^{5} \mathrm{~mol}^{-1} \mathrm{Ls}^{-1}$, consistent with that reported in the literature ${ }^{[54]}$ at $\mathrm{pH}=7.8$ $\left(1.0 \times 10^{5} \mathrm{~mol}^{-1} \mathrm{~L} \mathrm{~s}^{-1}\right)$. The effect of either 3 or 4 on the superoxide decay was tested for different concentrations of complex $\left(2 \times 10^{-7}, 10^{-5} \mathrm{~mol} \mathrm{~L}^{-1}\right.$ for 3 and $2.14 \times 10^{-7}$, $2.14 \times 10^{-6}$, and $2.14 \times 10^{-5} \mathrm{~mol} \mathrm{~L}^{-1}$ for $\mathbf{4}$, with an initial superoxide concentration $\left.\left[\mathrm{O}_{2}{ }^{-}\right]_{0}=7.3 \times 10^{-5} \mathrm{~mol} \mathrm{~L}^{-1}\right)$. From the absorbance decay at $270 \mathrm{~nm}$, kinetic constants were deduced (see Exp. Sect.). The catalytic rate constants $k_{\text {cat }}$ were obtained (see Exp. Sect.). They are reported in Table 5.

The apparent first-order kinetics observed for the superoxide decay in the presence of either complex, under conditions where $n_{\text {complex }}<n_{\text {superoxide }}$ showed that both $\mathbf{3}$ and $\mathbf{4}$ act as true catalysts for superoxide dismutation. The derived catalytic rate constant for $\mathbf{3}$ is of the same order of magnitude than that calculated from the IC50 values obtained by the McCord-Fridovich assay. For 4, rate constants obtained from both methods are in good agreement. ${ }^{[60]}$

This pulse radiolysis experiment is strong evidence for the catalytic behavior of $\mathbf{3}$ and $\mathbf{4}$. This conclusion concerning $\mathbf{3}$ is reinforced by further pulse radiolysis experiments that is described elsewhere. ${ }^{[61]}$

\section{Correlation between SOD Activity and Potentials}

As shown above, all redox potentials of the complexes of this series are in the expected range for the catalysis of superoxide dismutation. A linear correlation can be found between anodic half-wave potentials for the $\mathrm{Mn}^{\mathrm{III}} / \mathrm{Mn}^{\mathrm{II}}$ couple and $\log \left(k_{\mathrm{McCF}}\right)$ with a negative slope, as shown in Figure 8 . Within this series, the activity can be improved by a stabilization of the $+_{\text {III }}$ oxidation state: the rate-limiting step is the oxidation into $\mathrm{Mn}^{\mathrm{III}}$. Similar correlations have been described previously: (a) in the case of different series of $\mathrm{Mn}^{\mathrm{III}}$-porphyrins, ${ }^{[9,23,49]}$ with a positive slope, indicating that the reduction to $\mathrm{Mn}^{\mathrm{II}}$ was the rate-limiting step and; (b) in the case of $\mathrm{Fe}^{\mathrm{II}}$ complexes with a negative slope, indicating that the oxidation to iron(III) was the rate-limiting step. ${ }^{[62]}$
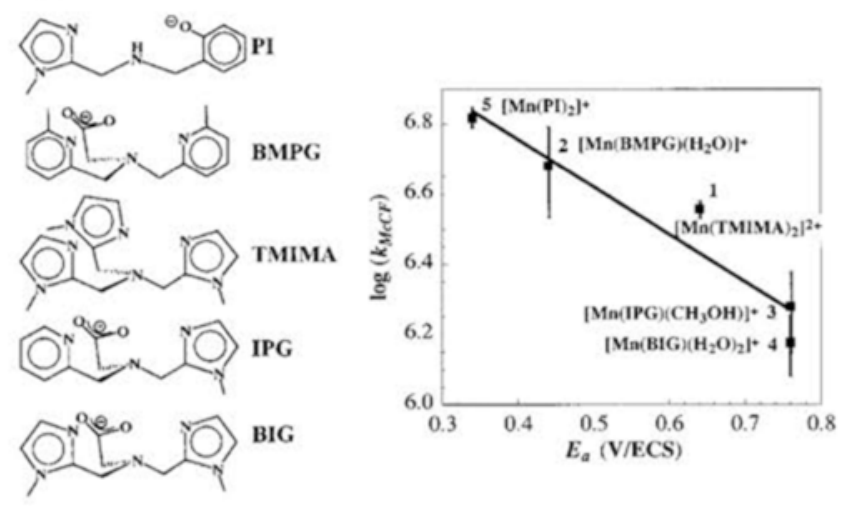

Figure 8. Correlation between $E_{a}$ and $\log \left(k_{\mathrm{McCF}}\right)$.

\section{Conclusions}

The new Mn complexes $\mathbf{1}$ and $\mathbf{5}$, whose structures are presented here, are part of a series of $\mathrm{Mn}$ complexes that were studied as SOD mimics. Reactivity in an anhydrous medium was described for $\mathbf{1}$ and $\mathbf{2}$ and compared with that of $\mathbf{3}$ and $\mathbf{4}$, previously published. ${ }^{[1]}$ The SOD activity was evaluated through the McCord-Fridovich assay and pulse radiolysis. IC50 values directly obtained from the McCordFridovich assay, are dependent on the experimental conditions used-that is on the concentration of the detector and its concentration. The results are thus provided and discussed here as derived values, $k_{\mathrm{McCF}}$. We suggest that $k_{\mathrm{McCF}}$ should be more commonly used, as IC50 values are not comparable from one experiment to the other if different detectors or different concentrations of the same detector were used. The SOD activity in this series is found to be within the reported range for $\mathrm{Mn}^{\mathrm{II}}$ compounds (see Table 5). The redox properties of the complexes from this series were studied by cyclic voltammetry in a collidine buffer. The potentials of the complexes of the series were tuned both by inducing steric constraints and by increasing the Lewis donor character of the ligands. The present article shows a linear trend between the anodic half-wave potential and $\log \left(k_{\mathrm{McCF}}\right)$ with a negative slope, indicating that the SOD activity in such a series can be improved by lowering the redox potential. Some new compounds are now under investigation to improve SOD activity.

\section{Experimental Section}

General: IR spectra $(\mathrm{KBr})$ were recorded with a Bruker IFS 66 FTIR spectrometer. ${ }^{1} \mathrm{H}$ NMR spectra were recorded with a Bruker AM 250 spectrometer $\left({ }^{1} \mathrm{H}, 250 \mathrm{MHz}\right)$ or a Bruker AC $360\left({ }^{1} \mathrm{H}\right.$, $360 \mathrm{MHz}$ ). Cyclic voltammetry experiments were performed with an AUTOLAB potentiostat. Electronic absorption spectra were recorded with a Safas 190 DES double-mode spectrophotometer. Chemical reagents were purchased either from Aldrich or Acros and used without further purification. Xanthine oxidase and ferricytochrome $\mathrm{c}$ were purchased from Sigma.

Syntheses and Characterization

$\mathrm{N}, \mathrm{N}, \mathrm{N}$-Tris|(1-methyl-2-imidazolyl)methyl|amine (TMIMA): A solution of $N, N$-bis[(1-methyl-2-imidazolyl)methyl]amine ${ }^{[40]}$ (see also refs. $\left.{ }^{[14,63,64]}\right)(4.1 \mathrm{~g}, 0.02 \mathrm{~mol})$ with 1-methyl-2-imidazolcarbaldehyde $(2.5 \mathrm{~g}, 0.02 \mathrm{~mol})^{[16]}$ in non-anhydrous $\mathrm{MeOH}(150 \mathrm{~mL})$ was hydrogenated in the presence of $\mathrm{Pd} / \mathrm{C}(10 \%)$ for $3 \mathrm{~d}$. $\mathrm{Pd} / \mathrm{C}$ was removed by filtration and the supernatant was concentrated to dryness. The white solid was purified by precipitation in $\mathrm{CH}_{3} \mathrm{Cl} / \mathrm{Et}_{2} \mathrm{O}$. Yield: $90 \%$. M.p. $200{ }^{\circ} \mathrm{C}$. ${ }^{1} \mathrm{H}$ NMR $\left(250 \mathrm{MHz}, \mathrm{CD}_{3} \mathrm{OD}\right): \delta=3.0$ (s, $\left.9 \mathrm{H}, \mathrm{CH}_{3} \mathrm{~N}\right), 3.8\left(\mathrm{~s}, 6 \mathrm{H}, 3 \mathrm{im}-\mathrm{CH}_{2} \mathrm{~N}\right), 6.7$ (d, $J=2.3 \mathrm{~Hz}, 3 \mathrm{H}$, $\left.\mathrm{H}_{\mathrm{im}}\right), 6.9\left(\mathrm{~d}, J=2.3 \mathrm{~Hz}, 3 \mathrm{H}, \mathrm{H}_{\mathrm{im}}\right) \mathrm{ppm} .{ }^{13} \mathrm{C} \mathrm{NMR}(62 \mathrm{MHz}$, $\left.\mathrm{CD}_{3} \mathrm{OD}\right): \delta=31.7\left(\mathrm{CH}_{3} \mathrm{~N}\right), 48.7\left(\mathrm{NCH}_{2}\right.$-im $), 121.3\left(\mathrm{C}_{4 \mathrm{im}}\right), 127.3$ $\left(\mathrm{C}_{5 \mathrm{im}}\right), 145.4\left(\mathrm{C}_{2 \mathrm{im}}\right) \mathrm{ppm}$. IR $(\mathrm{KBr}$; strong bands only): $\tilde{\mathrm{v}}=1495.8$ $\left(v_{\mathrm{im}}\right), 749.3\left(\delta_{\mathrm{im}}\right) \mathrm{cm}^{-1}$. ESI-MS: $m / z(\%)=300.2(30)[\mathrm{M}+\mathrm{H}]$, $322.2,(10)[\mathrm{M}+\mathrm{Na}]$.

[2-(Methylamino)phenol]: This protocol was inspired from a published aliphatic nitrile reduction procedure. ${ }^{[65]}$ 2-Cyanophenol (4 g, $33.6 \mathrm{mmol})$ was dissolved in $\mathrm{EtOH}(120 \mathrm{~mL})$. An aqueous solution $(20 \mathrm{~mL})$ of $\mathrm{NaOH}(5 \mathrm{~g}, 125 \mathrm{mmol})$ and Raney nickel (about $3 \mathrm{~g}$ ) were then added. The resulting suspension was stirred under $\mathrm{H}_{2}$ (40 bars) for $4 \mathrm{~h}$. After decantation of the nickel, the solution was filtered and $\mathrm{EtOH}$ was evaporated. $\mathrm{CH}_{2} \mathrm{Cl}_{2}(30 \mathrm{~mL})$ was added and the $\mathrm{pH}$ of the aqueous phase was brought to 9.3 by addition of $2 \mathrm{~N}$ 
Table 5. IC50 values and kinetic catalytic constants: comparison with the literature.

\begin{tabular}{|c|c|c|c|}
\hline Complex & IC $50^{\lfloor a\rfloor}$ & $k_{\text {cat }}\left[\mathrm{mol}^{-1} \mathrm{Ls}^{-1}\right]^{|c|}$ & Ref. \\
\hline$\left[\mathrm{Fe}^{\mathrm{III}}(\mathrm{IPG}) \mathrm{Cl}_{2}\right]$ & $I C 50_{22 \mu \mathrm{m} \mathrm{Cytc}}=2.7 \times 10^{-4} \mathrm{~mol} \mathrm{~L}^{-1}$ & $2.1 \times 10^{4} \mathrm{IT}$ & [39] \\
\hline$\left[\mathrm{Mn}^{\prime \prime}\left(\mathrm{ClO}_{4}\right)_{2}\right]+$ EDTA & $I C 50_{22 \mu \mathrm{m} \mathrm{Cyte}}=1.67 \pm 3 \times 10^{-4} \mathrm{~mol} \mathrm{~L}^{-1}$ & $3.4 \pm 0.1 \times 10^{4} \mathrm{IT}$ & [i] \\
\hline$\left[\mathrm{Fe}^{\mathrm{III}}(\mathrm{BIG}) \mathrm{Cl}_{2}\right]$ & $I C 50_{22 \mu \mathrm{m} \mathrm{Cytc}}=1.4 \times 10^{-4} \mathrm{~mol} \mathrm{~L}^{-1}$ & $4.1 \times 10^{4} \mathrm{IT}$ & {$[39,40]$} \\
\hline$\left[\mathrm{Mn}^{\prime \prime \prime}(\mathrm{DFB})\right]$ & $I C 50_{6.7 \mu \mathrm{m} \mathrm{Cyte}}=1.04 \times 10^{-5} \mathrm{~mol} \mathrm{~L}^{-1}$ & $1.0 \times 10^{6} \mathrm{IT}$ & [32] \\
\hline$\left[\mathrm{Mn}^{\prime \prime \prime}(\mathrm{TBAP})\right]^{+}$ & $I C 50_{10 \mu \mathrm{m} \mathrm{Cyt} \mathrm{c}}=9.2 \times 10^{-6} \mathrm{~mol} \mathrm{~L}^{-1}$ & $2.8 \times 10^{5} \mathrm{IT}$ & [41] \\
\hline$\left[\mathrm{Mn}^{\prime \prime}(\mathrm{PA})_{2}(\mathrm{PAH})\left(\mathrm{H}_{2} \mathrm{O}\right)\right]$ & $I C 50_{50 \mu \mathrm{m} \mathrm{NBT}}=6.5 \times 10^{-6} \mathrm{~mol} \mathrm{~L}^{-1}$ & $4.6 \times 10^{5} \mathrm{IT}$ & {$[42,43]$} \\
\hline$\left[\mathrm{Mn}^{\prime \prime \prime}(\mathrm{TPAC})\right]$ & $I C 50_{\mathrm{XTT}}=(0.33 \pm 0.014) \times 10^{-5} \mathrm{~mol} \mathrm{~L}^{-1}[\mathrm{~b}]$ & $(9.3 \pm 0.4) \times 10^{5} \mathrm{IT}$ & [44] \\
\hline$\left[\mathrm{Mn}^{\prime \prime}(\mathrm{TPAA})\right]\left(\mathrm{PF}_{6}\right)_{2}$ & IC $50_{22 \mu \mathrm{m} \mathrm{cyte}}=4.3 \times 10^{-6} \mathrm{~mol} \mathrm{~L}^{-1}$ & $1.3 \times 10^{6} \mathrm{IT} ; 1.05 \times 10^{7} \mathrm{PR}$ & [28] \\
\hline$\left[\mathrm{Mn}^{11}\left(\mathrm{ClO}_{4}\right)_{2}\right]$ & $I C 50_{22 \mu \mathrm{m} \mathrm{cytc}}=4.5 \pm 0.5 \times 10^{-6} \mathrm{~mol} \mathrm{~L}^{-1}$ & $1.3 \pm 0.2 \times 10^{6} \mathrm{IT}$ & [1] \\
\hline 4 & $I C 50_{22 \mu \mathrm{m} \mathrm{cyt} c}=3.7 \pm 0.6 \times 10^{-6} \mathrm{~mol} \mathrm{~L}^{-1}$ & $1.5 \pm 0.3 \times 10^{6} \mathrm{TT} ; 1.4 \pm 0.1 \times 10^{6} \mathrm{PR}$ & [1]; this work \\
\hline 3 & $I C 50_{22 \mu \mathrm{m} \mathrm{cytc}}=3.0 \pm 0.6 \times 10^{-6} \mathrm{~mol} \mathrm{~L}^{-1}$ & $1.9 \pm 0.5 \times 10^{6} \mathrm{Tr} ; 3.8 \pm 0.2 \times 10^{6 \mathrm{PR}}$ & [1]; this work \\
\hline 1 & $I C 50_{22} \mathrm{mcyt}_{\mathrm{c}}=1.6 \pm 0.1 \times 10^{-6} \mathrm{~mol} \mathrm{~L}^{-1}$ & $3.6 \pm 0.2 \times 10^{6} \mathrm{IT}$ & this work \\
\hline$\left[\mathrm{Mn}^{\prime \prime}(\mathrm{NTB})(\right.$ salicylate $\left.)\right] \mathrm{ClO}_{4}$ & $I C 50_{46 \mu \mathrm{m} \mathrm{NBT}}=0.7 \times 10^{-6} \mathrm{~mol} \mathrm{~L}^{-1}$ & $3.9 \times 10^{6} \mathrm{TT}$ & [45] \\
\hline $\mathrm{Mn}^{\prime \prime}(\mathrm{Obz})\left(3,5-i \mathrm{Pr}_{2} \mathrm{pzH}\right)\left(\mathrm{HB}\left(3,5-i \mathrm{Pr}_{2} \mathrm{pz}\right)_{3}\right)$ & $I C 50_{50 \mu \mathrm{m} \mathrm{NBT}}=0.75 \times 10^{-6} \mathrm{~mol} \mathrm{~L}^{-1}$ & $4.0 \times 10^{6} \pi$ & [42] \\
\hline [Mn"(NTB)(terephthalate)] & $I C 50_{46}$ um NBT $=0.64 \times 10^{-6} \mathrm{~mol} \mathrm{~L}^{-1}$ & $4.3 \times 10^{6} \mathrm{IT}$ & [46] \\
\hline 2 & $I C 50_{22 \mu \mathrm{m} \mathrm{cyt}}=1.2 \pm 0.5 \times 10^{-6} \mathrm{~mol} \mathrm{~L}^{-1}$ & $4.8 \pm 1.4 \times 10^{6} \mathrm{IT}$ & this work \\
\hline 5 & $I C 50_{22} \mu \mathrm{m} \mathrm{cytc}=8.7 \pm 0.6 \times 10^{-7} \mathrm{molL}^{-1}$ & $6.6 \pm 0.5 \times 10^{6} \mathrm{IT}$ & this work \\
\hline$\left[\mathrm{Mn}^{\mathrm{I}}\{N, N \text {-bis(2-pyridylmethyl)- }(S) \text {-histidinate }\}\left(\mathrm{H}_{2} \mathrm{O}\right)\right]_{2}\left(\mathrm{ClO}_{4}\right)_{2}$ & $I C 50_{10 \mu \mathrm{m} \mathrm{Cyt} \mathrm{c}}=2.9 \times 10^{-7} \mathrm{~mol} \mathrm{~L}^{-1}$ & $9.0 \times 10^{6} \mathrm{rr}$ & [30] \\
\hline$\left[\mathrm{Mn}^{\mathrm{I}}(\mathrm{EDTB})(\mathrm{Ac})\right] \mathrm{Ac} \cdot \mathrm{EtOH}$ & - & $1.0 \times 10^{7} \mathrm{IT}$ & [38] \\
\hline M40403 & - & $1.6 \times 10^{7 \mathrm{SF}}$ & [47] \\
\hline$\left[\mathrm{Mn}^{\mathrm{III}}(\mathrm{BVDME})\right]_{2}$ & $I C 50_{10 \mu \mathrm{m} \mathrm{Cytc}}=5.0 \times 10^{-8} \mathrm{~mol} \mathrm{~L}^{-1}$ & $5.0 \times 10^{7} \mathrm{rT}$ & [48] \\
\hline 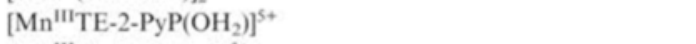 & $I C 50_{10 \mu \mathrm{m} \mathrm{Cytc}}=4.5 \times 10^{-8} \mathrm{~mol} \mathrm{~L}^{-1}$ & $5.8 \times 10^{7} \mathrm{IT}$ & [23] \\
\hline$\left[\mathrm{Mn}^{\mathrm{III}} \mathrm{Cl}_{4} \mathrm{TE}-2-\mathrm{PyP}\right]^{5+}$ & $I C 50_{10 \mu \mathrm{m} \mathrm{Cytc}}=6.5 \times 10^{-9} \mathrm{~mol} \mathrm{~L}^{-1}$ & $4.0 \times 10^{8} \mathrm{rT}$ & [49] \\
\hline$S, S$-Dimethyl-M40403 & - & $1.6 \times 10^{9} \mathrm{SF}$ & [so] \\
\hline
\end{tabular}

[a] $50 \%$ inhibition concentration. Indices specify the UV/Vis probe (cytc $\mathrm{Fe}^{\mathrm{III}}$ or NBT) concentration used for the test. $k_{\text {cat }}$ is the catalytic constant directly measured by pulsed radiolysis or stopped-flow techniques and $k_{\mathrm{McCF}}$ are recalculated kinetic constants from the $I C 50$ value. [b] Measured with XTT as UV/Vis probe. ${ }^{[51]} k_{\text {cat }}$ was directly provided in the article, by comparison with SOD. ${ }^{[52]}$ [c] IT: indirect test; SF: stopped flow; PR: pulsed radiolysis. DFB: desferrioxamine B; TBAP: 5,10,15,20-tetrakis(4-benzoic acid)porphyrin; PA: picolinate; TPAC: cis,cis-1,3,5-tri\{(5-trimethylammonium)-2-hydroxypicolyl)amino\}cyclohexane; salen: $N, N^{\prime}$-bis(salicylideneamino)ethane;

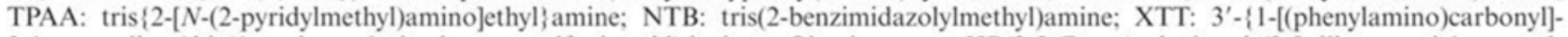
3,4-tetrazolium \} bis(4-methoxy-6-nitrobenzenesulfonic acid) hydrate; Obz: benzoate; $\mathrm{HB}\left(3,5-\mathrm{Pr}_{2} \mathrm{pz}\right)_{3}$ : hydrotris(3,5-diisopropyl-1-pyrazolyl)borate; EDTB: $N, N, N^{\prime}, N^{\prime}$-tetrakis(2'-benzimidazolylmethyl)-1,2-ethanediamine; M40403 and $S, S$-dimethyl-M40403: $\mathrm{Mn}^{\prime \prime}$ complexes from modified 1,4,7,10,13-pentaazacyclopentadecane ligands; BVDME: biliverdine IX dimethyl ester; TE-2-PyP: 5,10,15,20-tetrakis( $N$ ethylpyridinium-2-yl)porphyrin.

reported for $\mathrm{Mn}^{\mathrm{II}}$ complexes. Compound $\mathbf{5}$ is the best within this series. IC50 values for $\mathrm{Mn}^{\mathrm{II}}$ complexes $\mathbf{3}$ and $\mathbf{4}$ are far better than those reported for the corresponding $\mathrm{Fe}^{\mathrm{III}}$ complexes. Mn seems to be a most suitable ion for SOD mimics, as it is the least toxic of the $\mathrm{Fe}, \mathrm{Co}, \mathrm{Ni}, \mathrm{Cu}$, Mn series. Moreover, the best SOD mimic reported so far is a $\mathrm{Mn}^{\mathrm{II}}$ complex (see Table 5).

\section{Pulse Radiolysis (for 3 and 4)}

This McCord-Fridovich assay, as a determination of catalytic SOD-like activity is controversial. It has been shown, using stopped-flow techniques, ${ }^{[8,33]}$ or pulse radiolysis, ${ }^{[28]}$ that such an indirect test can be positive in the case of both a catalytic and a stoichiometric superoxide scavenger. As a matter of fact, in the McCord-Fridovich assay, superoxide is produced in low amounts. For compounds displaying high IC50 values (over $1 \mu \mathrm{molL}^{-1}$ ), the conditions required to probe a catalytic behavior may not be fulfilled if $n_{\text {complex }}>>n_{\text {superoxide }}$ in the experiment. However, this test remains relevant as the $\mathrm{X} / \mathrm{XO}$ system provides a stationary state of superoxide of low concentration, which is closer to what is usually encountered in vivo. ${ }^{[11,24]}$ Moreover, in the case of a small IC50 value indicative of a cata- lytic activity, the $k_{\mathrm{McCF}}$ value derived from the $I C 50$ value (see above) corresponds to the $k_{\text {cat }}$.

To test the catalytic behavior within the series, we studied the reactivity of $\mathbf{3}$ and $\mathbf{4}$ by pulse radiolysis. They were chosen because they have the highest IC50 values of the series, i.e. they were the slowest of the series.

Pulse radiolysis was used to produce the superoxide radical by irradiation of oxygenated aqueous solutions with high energy ionizing radiation. ${ }^{[53]}$ Primary radicals $\left(\mathrm{H}^{*}, \mathrm{e}^{-}\right.$aq, $\mathrm{HO}^{*}$ ) are rapidly and quantitatively converted into either superoxide $\mathrm{O}_{2}^{-}$or its protonated form hydroperoxyl $\mathrm{HO}_{2}$, in the presence of either formate or alcohols. ${ }^{[54,55]}$ Propan2-ol was chosen as formate might coordinate to Mn. The aqueous solution, driven at a constant rate through the UV/ Vis microcell, was irradiated for a short time period with an irradiation frequency $(1 \mathrm{~Hz})$ chosen so that between two pulses the solution was totally renewed. Absorbances were averaged over 100 pulses. This setup provides an improvement of the signal to noise ratio, by comparison with generally used single-pulse experiments. ${ }^{[56-59]}$

Superoxide decay was directly monitored at $270 \mathrm{~nm}$, in aqueous phosphate buffer solutions $\left(5 \mathrm{mmol} \mathrm{L}^{-1}, \mathrm{pH}=7.8\right)$. Spontaneous decay of $\mathrm{O}_{2}^{-}$followed a second order rate law, as expected for autodismutation of superoxide. The ob- 
$\mathrm{HCl}$. The organic phase was decanted and the aqueous phase was further extracted 3 times with small portions of $\mathrm{CH}_{2} \mathrm{Cl}_{2}$. The organic phase was dried $\left(\mathrm{Na}_{2} \mathrm{SO}_{4}\right)$ and the solvents were evaporated. 2-(Methylamino)phenol ( $2.42 \mathrm{~g}$, yield $59 \%$ ) was obtained as a white solid. The nonquantitative yield is probably due to the formation of the $\mathrm{Ni}^{\prime \prime}$ complex which gives a blue-green coloration to the aqueous phase. ' $\mathrm{H}$ NMR ( $\left.250 \mathrm{MHz}, \mathrm{CDCl}_{3}\right): \delta=1.25$ (br. s, $\mathrm{NH}_{2}$ ), 4.14 (s, $\left.2 \mathrm{H}, \mathrm{CH}_{2}\right), 6.81$ (m, $\left.2 \mathrm{H}, \mathrm{Ar}\right), 6.98$ (d, $\left.J=5 \mathrm{~Hz}, 1 \mathrm{H}, \mathrm{Ar}\right)$, $7.18(\mathrm{t}, J=7.5 \mathrm{~Hz}, 1 \mathrm{H}, \mathrm{Ar}) \mathrm{ppm}$.

2-(\{l(1-Methyl-2-imidazolyl)methyl]amino\}methyl)phenol (PIH): 2(Methylamino)phenol $(1 \mathrm{~g}, 8.1 \mathrm{mmol})$ and 1-methyl-2-imidazolecarbaldehyde $(0.89 \mathrm{~g}, 8.1 \mathrm{mmol})$, synthesized according to a published procedure ${ }^{[16]}$ were dissolved in anhydrous $\mathrm{EtOH}(80 \mathrm{~mL})$. This solution was heated to reflux over $3 \mathrm{~h}$ and thencooled to ambient temperature. $\mathrm{NaBH}_{4}(0.384 \mathrm{~g}, 10.2 \mathrm{mmol})$ was then added in small portions over $15 \mathrm{~min}$ and the resulting solution was refluxed for $5 \min .2 \mathrm{~N}$ aqueous $\mathrm{HCl}$ was then added until the end of gaseous release. EtOH was evaporated and $\mathrm{CH}_{2} \mathrm{Cl}_{2}(30 \mathrm{~mL})$ was added. The $\mathrm{pH}$ of the aqueous phase was brought to 9.5 by addition of a $2 \mathrm{~N}$ aqueous $\mathrm{NaOH}$ solution. The organic phase was decanted and the aqueous phase was further extracted 3 times with small portions of $\mathrm{CH}_{2} \mathrm{Cl}_{2}$. The joint organic phases were dried $\left(\mathrm{Na}_{2} \mathrm{SO}_{4}\right)$ and the solvents evaporated. PIH $(1.2 \mathrm{~g}$, yield $68 \%$ ) was obtained as an orange oil. ${ }^{1} \mathrm{H}$ NMR $\left(360 \mathrm{MHz}, \mathrm{CDCl}_{3}\right): \delta=3.45$ $\left(\mathrm{s}, 3 \mathrm{H}, \mathrm{NCH}_{3}\right), 3.72\left(\mathrm{~s}, 2 \mathrm{H}, \mathrm{CH}_{2}\right), 3.87\left(\mathrm{~s}, 2 \mathrm{H}, \mathrm{CH}_{2}\right), 7.01$ (t, $J$ $=8 \mathrm{~Hz}, 1 \mathrm{H}, \mathrm{Ar}), 6.94(\mathrm{~d}, J=7.3 \mathrm{~Hz}, 1 \mathrm{H}, \mathrm{Ar}), 6.87$ (br s, $1 \mathrm{H}$, Ar), 6.74 (br. m, $3 \mathrm{H}, \mathrm{Ar}$ ) ppm. ${ }^{13} \mathrm{C}$ NMR $\left(90 \mathrm{MHz}, \mathrm{CDCl}_{3}\right): \delta=$ $32.3\left(\mathrm{~N}_{\mathrm{im}} \mathrm{CH}_{3}\right), 43.3$ and $51.0\left(\mathrm{~N}_{\mathrm{im}} \mathrm{CH}_{2}\right.$ and $\left.\mathrm{N}_{\mathrm{Ar}} \mathrm{CH}_{2}\right), 116.0,118.9$, $121.1,122.8,126.7,128.5,128.9,145.2$ (phenol and imidazole), $157.5\left(\mathrm{C}_{\mathrm{phenol}} \mathrm{OH}\right) \mathrm{ppm}$. IR ( $\mathrm{KBr}$; strong bands only): $\tilde{\mathrm{v}}=1456$ and $1489\left(v_{\text {im }}\right), 1255\left(v_{\text {phenol }}\right), 756\left(\delta_{\text {im }}\right) \mathrm{cm}^{-1}$. ESI-MS: $m / z(\%)=218.1$ (100) $[\mathrm{M}+\mathrm{H}]$.

Mn(TMIMA $)_{2}\left(\mathrm{PF}_{6}\right)_{2}$ (1): $\mathrm{An} \mathrm{MnBr}_{2}$ solution in distilled water $(125 \mathrm{mg}$ in $7 \mathrm{~mL}$ ) was added after deoxygenation (argon) to a hot $\left(40^{\circ} \mathrm{C}\right)$ deoxygenated methanolic solution of TMIMA (150 mg in $7 \mathrm{~mL}$ ). After $1.5 \mathrm{~h}$ at $40^{\circ} \mathrm{C}$, it was allowed to cool to room temp. A deoxygenated solution of ammonium hexafluorophosphate $(288 \mathrm{mg})$ in $\mathrm{MeOH} / \mathrm{H}_{2} \mathrm{O}(5 \mathrm{~mL}, 1: 1)$ was then added. Crystals suitable for X-ray diffraction were grown by slow concentration over 24 h. Yield: $50 \%, \mathrm{C}_{30} \mathrm{H}_{42} \mathrm{~F}_{12} \mathrm{MnN}_{14} \mathrm{P}_{2}$ (943.6): calcd. C $38.19, \mathrm{H}$ 4.49, F 24.16, Mn 5.82, N 20.78, P 6.56; found C 38.00, H 4.39, F 24.60, Mn 5.83, N 20.70, P 6.48. IR $(\mathrm{KBr}): \hat{v}=1503\left(v_{\text {im }}\right), 839$ $\left(\mathrm{PF}_{6}{ }^{-}\right), 741\left(\delta_{\text {im }}\right), 556\left(\mathrm{PF}_{6}{ }^{-}\right) \mathrm{cm}^{-1}$. Crystals of [Mn(TMIMA $\left.)_{2}\right]-$ $\left(\mathrm{PF}_{6}\right)_{2}(1)$ were obtained from a water/methanol solution as prismatic crystals. One of these, the size of which was $0.3 \times 0.6 \times 0.6 \mathrm{~mm}$, was mounted on a SMART 1000 Bruker AXS diffractometer with Mo- $K_{\alpha}$ radiation $(\lambda=0.7107 \AA)$. Atomic scattering factors were taken from ref. ${ }^{[66]}$ The structure was solved by direct methods using SIR97 ${ }^{[67]}$ and refined using SHELXL-97[68] on $F^{2}$ by full-matrix least squares with anisotropic displacement parameters for all non-hydrogen atoms. All hydrogen atoms were calculated in ideal geometrical positions. Final refinement gave $R_{1}$ $=0.0348$ and $w R_{2}=0.0984$. Experimental details for the X-ray data collection are reported in Table 6 . The refinement procedure was carried out using the WinGX package ${ }^{[69]}$ with the program PARST $^{[70]}$ for the geometrical description of the structures and ORTEP ${ }^{[71]}$ and PLUTO ${ }^{[72]}$ for the structure drawings.

$\left[\mathrm{Mn}(\mathrm{PI})_{2}\right]\left(\mathrm{CH}_{3} \mathrm{CN}\right)\left(\mathrm{PF}_{6}\right)$ (5): A deoxygenated aqueous solution $(8 \mathrm{~mL})$ of $\mathrm{MnBr}_{2}(124 \mathrm{mg}, 0.58 \mathrm{mmol})$ was added to a deoxygenated methanolic solution $(8 \mathrm{~mL})$ of PIH $(0.70 \mathrm{mmol}) . \mathrm{Et}_{3} \mathrm{~N}$ $(0.025 \mathrm{~g}, 0.25 \mathrm{mmol})$ was added. The resulting solution was allowed to stand for $1.5 \mathrm{~h}$ at ambient temperature under positive argon pressure. A deoxygenated solution $\left(2.5 \mathrm{~mL} \mathrm{H} \mathrm{H}_{2} \mathrm{O} / 2.5 \mathrm{~mL} \mathrm{MeOH}\right)$ of $\mathrm{NH}_{4} \mathrm{PF}_{6}(0.25 \mathrm{~g}, 1.53 \mathrm{mmol}, 2.6$ equiv. $)$ was then added. A white powder was then precipitated. The solid was filtered off and redissolved in $\mathrm{CH}_{3} \mathrm{CN}$. The solution turned violet and crystals of $\left[\mathrm{Mn}(\mathrm{PI})_{2}\right]\left(\mathrm{PF}_{6}\right) \cdot \mathrm{CH}_{3} \mathrm{CN}$ suitable for $\mathrm{X}$ ray diffraction were obtained in low yield ( $50 \%$ from the powder) from acetonitrile by diffusion of $t$ BuOMe as tiny dark crystals (see below). When the preparation was carried out at a higher temperature $\left(50^{\circ} \mathrm{C}\right)$ and under dioxygen, a purple black solution was obtained and a purple black powder was precipitated upon $\mathrm{NH}_{4} \mathrm{PF}_{6}$ addition. $\mathrm{C}_{24} \mathrm{H}_{28} \mathrm{~F}_{6} \mathrm{~N}_{6} \mathrm{O}_{2} \mathrm{MnP}\left(\mathrm{CH}_{3} \mathrm{CN}\right)_{0.5}\left(\mathrm{H}_{2} \mathrm{O}\right)_{1.5}$ (679.66): calcd. C 44.14, H 4.82, Mn 8.08, N 13.39, P 4.56; found C 44.30, H 4.51, Mn 7.99, $\mathrm{N} 13.37, \mathrm{P} 4.66$. IR ( $\mathrm{KBr}$; strong bands only): $\tilde{\mathrm{v}}=3438$ and 3339 $\left(v_{\mathrm{NH}}\right), 1595,1507,1477,1268\left(v_{\text {COphenol }}\right), 841\left(\mathrm{PF}_{6}\right), 779,767\left(\delta_{\text {im }}\right)$, $557\left(\mathrm{PF}_{6}\right) \mathrm{cm}^{-1}$. Among the crystals obtained a few specimens were chosen and tested for diffraction. All of them were very small and badly twinned. The best crystal found $(0.1 \times 0.1 \times 0.3 \mathrm{~mm})$ was mounted on a Philips diffractometer with Mo- $K_{\alpha}$ radiation $(\lambda=$ $0.7107 \AA$ ). Tabulated atomic scattering factors were taken from ref. ${ }^{[66]}$ The structure was solved by direct methods using SIR 97 ${ }^{[67]}$ and refined using SHELXL-97 $7^{[68]}$ on $F^{2}$ by full-matrix least squares with anisotropic displacement parameters for all atoms but the acetonitrile molecule and the hydrogen atoms. All hydrogen atoms were calculated in ideal geometrical positions. Because of its very small size the crystal used for structure characterization gave extremely weak diffraction. The final refinement suffers therefore from a very low ratio between the parameters to refine and the number of observed reflections. Final refinement gave $R_{1}=0.117$ and $w R_{2}=0.36$. Experimental details for the X-ray data collection are reported in Table 6 . The refinement procedure was carried out using the WinGX package ${ }^{[69]}$ with the program PARST ${ }^{[70]}$ for the geometrical description of the structures and ORTEP $[71]$ and PLUTO $^{[72]}$ for the structure drawings.

CCDC-245983 contains the supplementary crystallographic data for this paper. These data can be obtained free of charge from The Cambridge Crystallographic Data Centre via www.ccdc.cam.ac.uk/ data_request/cif.

Reactivity in Anhydrous DMSO with Superoxide: The protocol for studying the reactivity with $\mathrm{Mn}^{\mathrm{II}}$ complexes was the same as that previously published (preparation of superoxide solutions, spectrophotometric titration). ${ }^{[1]}$ Several aliquots were prepared with a final volume of $1 \mathrm{~mL}$, containing the complex and $n$ equiv. of superoxide. After the superoxide was added, the aliquot was manually stirred. $100 \mu \mathrm{L}$ was introduced in an EPR tube which was immediately frozen in an $\mathrm{EtOH} / \mathrm{N}_{2}$ (liq) bath and then kept in $\mathrm{N}_{2}$ (liq). EPR spectra were then recorded. For each experiment, the superoxide was quantified by EPR from the intensity of the $g_{x y}=2.00$ peak and a linear correlation with concentration was found (see Supporting information). This was used to quantify the remaining superoxide within each EPR tube.

Cyclic Voltammetry Experiments: Cyclic voltammetry experiments were performed at room temperature with an argon stream in a collidine buffer $\left(\mathrm{pH}=7.5 ; 50 \mathrm{mmol} \mathrm{L}^{-1}\right)$. The working electrode was a vitreous carbon disk. The reference electrode was an SCE, saturated with $\mathrm{KCl}$. Concentrations of the complexes were $2 \times 10^{-3} \mathrm{~mol} \mathrm{~L}^{-1}$ and $6 \times 10^{-4} \mathrm{~mol} \mathrm{~L}^{-1}$ on the basis of $\mathrm{Mn}^{11}$ content.

McCord-Fridovich Assay or Xanthine-Xanthine Oxidase-Cytochrome c Assay: The superoxide anion was supplied to the system from the xanthine-xanthine oxidase reaction.

Reliability of the McCord-Fridovich Assay: To check that the tested compounds do not inhibit the production of superoxide by xanthine oxidase, the rate of conversion of xanthine to urate (see be- 
Table 6. Crystal data for complexes $\left[\mathrm{Mn}\left(\mathrm{TMIMA}_{2}\right]\left(\mathrm{PF}_{6}\right)_{2}(\mathbf{1})\right.$ and $\left[\mathrm{Mn}(\mathrm{PI})_{2}\right]\left(\mathrm{PF}_{6}\right)\left(\mathrm{CH}_{3} \mathrm{CN}\right)(\mathbf{5})$.

\begin{tabular}{|c|c|c|}
\hline & 1 & 5 \\
\hline Empirical formula & $\mathrm{C}_{30} \mathrm{H}_{42} \mathrm{~F}_{12} \mathrm{MnN}_{14} \mathrm{P}_{2}$ & $\mathrm{C}_{26} \mathrm{H}_{31} \mathrm{MF}_{6} \mathrm{n}_{1} \mathrm{~N}_{7} \mathrm{O}_{2} \mathrm{P}$ \\
\hline Formula mass & 943.622 & 673.5 \\
\hline Crystal system & monoclinic & triclinic \\
\hline Space group & $P 2, / c$ & $P \overline{1}$ \\
\hline$a[\AA]]$ & $12.295(2)$ & $11.815(11)$ \\
\hline$b[\hat{A}]$ & $13.879(3)$ & $13.318(13)$ \\
\hline$c[\AA]$ & $12.720(2)$ & $10.770(9)$ \\
\hline$a\left[^{\circ}\right]$ & 90 & $94.91(5)$ \\
\hline$\beta\left[\left[^{\circ}\right]\right.$ & $109.43(2)$ & $112.79(7)$ \\
\hline$\gamma\left[^{\circ}\right]$ & 90 & $80.84(7)$ \\
\hline$V\left[\AA^{3}\right]$ & $2129.4(8)$ & $1542(3)$ \\
\hline$Z$ & 2 & 2 \\
\hline$F(000)$ & 966 & 692 \\
\hline$D_{\text {calcd. }}\left[\mathrm{mg} \mathrm{m}^{-3}\right]$ & 1.531 & 1.45 \\
\hline$\mu\left(\mathrm{Mo}-K_{\alpha}\right)\left[\mathrm{mm}^{-1}\right]$ & 0.4987 & 0.71069 \\
\hline Crystal size [mm] & $0.4 \times 0.6 \times 0.6$ & $0.1 \times 0.1 \times 0.3$ \\
\hline$T[\mathrm{~K}]$ & 293 & 293 \\
\hline No. of reflections measured & 18649 & 5409 \\
\hline$\theta$ range $\left[{ }^{\circ}\right]$ & $2.00<2 \theta<50.00$ & $3.00<2 \theta<60.00$ \\
\hline$h \mathrm{kl}$ ranges & $-13,13 ;-15,15 ;-14,14$ & $-14,12 ;-15,15 ; 0,12$ \\
\hline No. of unique reflections & 2950 & 5409 \\
\hline No. of reflections observed $[I>2 \sigma(I)]$ & 2381 & 887 \\
\hline No. of parameters & 323 & 372 \\
\hline$R_{1}^{\text {[a] }}$ & 0.0348 & 0.117 \\
\hline Weight $(A, B)^{[b]}$ & $0.0523,0.54$ & $0.1122,0.00$ \\
\hline$w R_{2}[\mathrm{c}]$ & 0.0984 & 0.368 \\
\hline Max. Fourier difference $\left[\mathrm{e} / \AA^{3}\right]$ & $0.28,-0.16$ & $0.56,-0.64$ \\
\hline
\end{tabular}

[a] $\left.R_{1}=\Sigma|| F_{\mathrm{o}}|-| F_{\mathrm{c}} \| / \Sigma\left|F_{\mathrm{o}}\right| \cdot[\mathrm{b}] 1 / \sigma^{2}\left(F_{\mathrm{o}}{ }^{2}\right)+(A \cdot P)^{2}+B \cdot P\right]$ where $P=\left[\operatorname{Max}\left(F_{\mathrm{o}}{ }^{2}, 0\right)+2 \cdot F_{\mathrm{c}}{ }^{2}\right] / 3 .[\mathrm{c}] w R_{2}=\left\{\Sigma\left[w\left(F_{\mathrm{o}}{ }^{2}-F_{\mathrm{c}}{ }^{2}\right)^{2} / \Sigma\left[w\left(F_{\mathrm{o}}{ }^{2}\right)^{2}\right]\right\}^{1 / 2}\right.$.

low) was determined by measuring the increase in absorbance at $290 \mathrm{~nm}$ over a 2 -min period with and without the tested compounds. At concentrations higher than the IC50 value, no inhibition of this conversion was recorded. We also checked that ferricytochrome $\mathrm{c}$ was stable in the presence of the putative SOD mimics.

Xanthine to Urate Assay: To measure the rate of conversion of xanthine to urate, xanthine oxidase $\left(30 \mu \mathrm{L}\right.$ of $\left.0.77 \mathrm{UmL}^{-1} \mathrm{XO}\right)$ was added to a solution of potassium phosphate buffer $(\mathrm{pH}=7.8$; $\left.50 \mathrm{mmol} \mathrm{L}^{-1}\right)$ containing xanthine $\left(150 \mu \mathrm{mol} \mathrm{L}^{-1}\right)$ at a final volume of $1.0 \mathrm{~mL}$ at $25^{\circ} \mathrm{C}$. Urate production was monitored at $290 \mathrm{~nm}$. No difference in the slope was recorded with or without the putative SOD mimics.

Reduction of Ferricytochrome c: Activities were measured using ferricytochrome c reduction. ${ }^{[1,31,33,73]}$ The assay was performed at $25^{\circ} \mathrm{C}$ in $3 \mathrm{~mL}$ of reaction buffer $\left(50 \mathrm{mmol} \mathrm{L}^{-1}\right.$ potassium phosphate buffer, $\mathrm{pH}=7.8)$ containing ferricytochrome $\mathrm{c}\left(22 \mu \mathrm{mol} \mathrm{L}^{-1}\right)$, xanthine $(200 \mu \mathrm{M})$, and an amount of xanthine oxidase such as to give a rate of $\triangle O D_{550 \mathrm{~mm}}=0.025 \mathrm{~min}^{-1}$ (about $0.01 \mathrm{UmL}^{-1}$ ) in the absence of a putative SOD mimic. A reduction of ferricytochrome c was monitored at $550 \mathrm{~nm}$. After $2 \mathrm{~min}$, different amounts of the putative SOD mimic were added. Rates were linear for at least $8 \mathrm{~min}$. Both rates in the absence and in the presence of the complex were determined for each concentration of complex added. The IC50 value represents the concentration of putative-SOD mimic that induces a $50 \%$ inhibition of the reduction of cytochrome c. If $s 1$ is the slope before addition of the putative SOD mimic and $s 2$ is the slope after addition of the putative SOD mimic, the inhibition percentage is given by $I(\%)=(s I-s 2) / s I \times 100$. For an $I C 50$ value determination, $I$ is measured for several concentrations in the range of the IC50. IC50 is obtained for $I=50 \% ;(s I-s 2) / s 2$ was also plotted against the complex concentration, providing a linear correlation. IC 50 is then obtained for $(s 1-s 2) / s 2=1^{[34]}$
Pulse Radiolysis Experiments: The pulse radiolysis experiment was carried out using a $10 \mathrm{MeV}$ Titan $\beta$ linear accelerator at the Laboratory of Radiolysis, CEA Saclay. Pulses can last between $5 \mathrm{~ns}$ and $1 \mu \mathrm{s}$, and the frequency between two pulses is adjustable. A $10 \mathrm{~ns}$ pulse corresponds to a 20 Gray dose. Solutions saturated with oxygen are driven in a quartz circulating microcell (spectral path length $1 \mathrm{~cm}$, volume $400 \mu \mathrm{L})$ at a constant flux $\left(1 \mathrm{~mL} \mathrm{~min}^{-1}\right)$. The spectroscopic and temporal analysis is mediated by an optical fiber, linked to a monochromator, then to a photomultiplier and lastly to a Tektronix numerical oscilloscope allowing the observation of the temporal evolution of absorbance. Absorbance was averaged over 100 pulses. It provides an improvement of the signal/noise ratio, by comparison with generally used single-pulse experiments. The amount of superoxide generated during pulse radiolysis was established by the absorbance value at $260 \mathrm{~nm}$, assuming that $\varepsilon_{260}=$ $1940 \mathrm{~mol} \mathrm{~L}^{-1} \mathrm{~cm}^{-1[54]}$ All measurements were carried out in propan2-ol $\left(100 \mathrm{mmol} \mathrm{L}^{-1}\right)$ in phosphate buffer $\left(5 \mathrm{mmol} \mathrm{L}^{-1}\right)$ at $\mathrm{pH}=7.8$ and $25^{\circ} \mathrm{C}$. Various amounts of complexes MnIPG or MnBIG were dissolved in that buffer. Solutions were oxygen-saturated by bubbling $\mathrm{O}_{2}$ for at least $60 \mathrm{~min}$. The electron pulse lasted $1 \mu \mathrm{s}$, generating a $7.3 \times 10^{-5} \mathrm{~mol} \mathrm{~L}^{-1}$ superoxide solution. The irradiation frequency was $1 \mathrm{~Hz}$, so that the cell content was totally renewed between two pulses. The disappearance of superoxide was monitored at $270 \mathrm{~nm}\left(\varepsilon_{270}=1479 \mathrm{~mol} \mathrm{~L}^{-1} \mathrm{~cm}^{-1}\right.$ at $\mathrm{pH}=7.8$ and $\left.23^{\circ} \mathrm{C}^{[53]}\right)$. Rates were derived assuming, either second-order kinetics corresponding to the auto-dismutation of superoxide $\left[O D=O D_{0} /(1+\right.$ $\left.k_{\text {obs }} O D_{0} t\right)$ ], or a pseudo-first order kinetics in the presence of complexes $\left\{O D=O D_{0}\left[\exp \left(-k_{\text {obs }} t\right)\right]+B, k_{\text {obs }}=k_{\text {cat }}[\right.$ complex $\left.]+A\right\}$. Simulations of kinetic traces are performed using Gepasi3 (autodismutation) or Kaleidagraph (complex catalyzed dismutation).

Supporting Information: See also the footnote on the first page of this article. A. Reference for statistical analysis of the $\mathrm{Mn}-\mathrm{N}$ dis- 
tances; B. additional crystallographic data for 1; C. EPR quantification of the superoxide content.

\section{Acknowledgments}

We would like to acknowledge the European Community for financial support (TMR contract FMRX-CT980174).

[1] C. Policar, S. Durot, F. Lambert, M. Cesario, F. Ramiandrasoa, I. Morgenstern-Badarau, Eur. J. Inorg. Chem. 2001, 1807-1818.

[2] Abbreviations: IPG $=N-[(1-$ methyl-2-imidazolyl $)$ methyl $]-N-(2-$ pyridylmethyl)glycinate; $\mathrm{BIG}=N, N$-bis[(1-methyl-2-imidazolyl)methyl]glycinate; TMIMA = tris[(1-methyl-2-imidazolyl)methyl $]$ amine; $\mathrm{BMPG}=N, N$-bis[(6-methyl-2-pyridyl)methyl $]$ glycinate; $\quad P I=2-\{[(1-$ methyl-2-imidazolyl $)$ methyl $]-$ amino\} phenolate; EPR = electron paramagnetic resonance; $I C 50=$ concentration that induces a diminution of $50 \%$ in the kinetic of reduction of ferricytochrome $\mathrm{c}$ in the McCord-Fridovich assay; $\mathrm{SOD}=$ superoxide dismutase; $\mathrm{SCE}$ : saturated calomel electrode; cyt c $=$ Cytochrome $\mathrm{c} \mathrm{Fe}{ }^{\mathrm{III}}$; NBT: nitro-blue tetrazolium; $\mathrm{X} / \mathrm{XO}=\mathrm{xanthine} / \mathrm{xanthine}$ oxidase. See also Table 5.

[3] I. Fridovich, Arch. Biochem. Biophys. 1986, 247, 1-11.

[4] I. Fridovich, Ann. Rev. Biochem. 1995, 64, 97-112.

[5] I. Fridovich, J. Biol. Chem. 1997, 272, 18515-18517.

[6] C. X. Zhang, S. J. Lippard, Curr. Opin. Chem. Biol. 2003, 7, 481-489.

[7] D. Salvemini, C. Muscoli, D. P. Riley, S. Cuzzocrea, Pulm. Pharmacol. Ther. 2002, 15, 439-447.

[8] D. P. Riley, Chem. Rev. 1999, 99, 2573-2587.

[9] I. Batinic-Haberle, I. Spasojevic, R. D. Stevens, P. Hambright, P. Neta, A. Okado-Matsumoto, I. Fridovich, J. Chem. Soc., Dalton Trans. 2004, 1696-1702.

[10] J. R. Anacona, M. Azocar, O. Nusetti, C. Rodriguez-Barbarin, Transition Met. Chem. 2003, 28, 24-28.

[11] J.-L. Pierre, P. Chautemps, S. Refaif, C. Beguin, A. El Marzuki, G. Serratrice, E. Saint-Aman, P. Rey, J. Am. Chem. Soc. 1995, $117,1965-1973$.

[12] M. A. Bailey, M. J. Ingram, D. P. Naughton, Biochem. Biophys. Res. Commun. 2004, 317, 1155-1158.

[13] S. Durot, C. Policar, F. Bisceglie, G. Pelosi, T. Mallah, J.-P. Mahy, Inorg. Chem. 2003, 42, 8072-8080.

[14] K. J. Oberhausen, R. J. O'Brien, J. F. Richardson, R. M. Buchanan, R. Costa, J.-M. Latour, H.-L. Tsai, D. N. Hendrickson, Inorg. Chim. Acta 1990, 173, 145.

[15] K. J. Oberhausen, R. J. O'Brien, J. F. Richardson, R. M. Buchanan, R. Costa, J.-M. Latour, H.-L. Tsai, D. N. Hendrickson, Inorg. Chem. 1993, 32, 4561-4565.

[16] P. E. Iberson, H. Lund, Acta Chem. Scand. 1966, 20, 2649.

[17] F. H. Allen, Acta Crystallogr., Sect. B 2002, 58, 380-388.

[18] The six hyperfine lines are broadened because of intermolecular interactions.

[19] In the case of 3 , the formation of a di- $\mu$-oxo- $\mathrm{Mn}^{\mathrm{III}} \mathrm{Mn}^{\mathrm{IV}}$ species was observed after addition 0.5 equiv. of superoxide. The di- $\mu$-oxo- $\mathrm{Mn}^{\text {III }} \mathrm{Mn}^{\text {IV }}$ species has been shown to be further reduced to a di- $\mu$-oxo- $\mathrm{Mn}^{\text {III }} \mathrm{Mn}^{\text {III }}$ species (1 equiv. of superoxide). In the case of $\mathbf{4}$, a similar behaviour was recorded upon addition of superoxide, but with a different stoichiometry. The $\mathrm{Mn}^{\mathrm{III}} \mathrm{Mn}^{\mathrm{IV}}$-di- $\mu$-oxo complex was obtained after addition of 1.5 equiv. of superoxide and the EPR-silent $\mathrm{Mn}^{\mathrm{III}} \mathrm{Mn}^{\mathrm{III}}-\mathrm{di}-\mu-$ oxo species was obtained after addition of 2 equiv. of superoxide. A mechanism involving the oxidation of the starting $\mathrm{Mn}^{\text {II }}$ complex to an $\mathrm{Mn}^{\mathrm{III}} \mathrm{Mn}^{\mathrm{IV}}$-di- $\mu$-oxo and then a reduction to the $\mathrm{Mn}^{\mathrm{III}} \mathrm{Mn}^{\mathrm{III}}$-di- $\mu$-oxo species has been proposed.

[20] W. C. J. Barrette, D. T. Sawyer, J. A. Fee, K. Asada, Biochemistry $1983,22,624-627$.

[21] W. H. Koppenol, F. Levine, T. L. Hatmaker, J. Epp, J. D. Rush, Arch. Biochem. Biophys. 1986, 251, 594-599.
[22] J. Stein, J. P. Fackler, G. J. Mcclune, J. A. Fee, L. T. Chan, Inorg. Chem. 1979, 18, 3511-3518.

[23] I. Batinic-Haberle, I. Spasojevic, P. Hambright, L. Benov, A. L. Crumbliss, I. Fridovich, Inorg. Chem. 1999, 38, 4011-4022.

[24] J.-L. Pierre, Regard sur la Biochimie 2000, 17-20.

[25] E. A. Lewis, J. R. Lindsay-Smith, P. H. Walton, S. J. Archibald, S. P. Foxo, G. M. P. Giblin, J. Chem. Soc., Dalton Trans. 2001, 1159_1161.

[26] M. G. B. Drew, C. J. Harding, V. Mckee, G. G. Morgan, J. Nelson, J. Chem. Soc. Chem. Commun. 1995, 1035-1038.

[27] F. C. Frederick, W. M. Coleman, L. T. Taylor, Inorg. Chem. $1983,22,792-795$.

[28] A. Deroche, I. Morgenstern-Badarau, M. Cesario, J. Guilhem, B. Keita, L. Nadjo, C. Houée-Levin, J. Am. Chem. Soc. 1996, 118, 4567-4573.

[29] Y. Nishida, N. Tanaka, A. Yamazaki, T. Tokii, N. Hashimoto, K. Ide, K. Iwasawa, Inorg. Chem. 1995, 34, 3616-3620.

[30] K. Yamato, I. Miyahara, A. Ichimura, K. Hirotsu, Y. Kojima, H. Sakurai, D. Shiomi, K. Sato, T. Takui, Chem. Lett. 1999 , 295-296.

[31] J. M. McCord, I. Fridovich, J. Biol. Chem. 1969, 244, 60496055.

[32] K. M. Faulkner, R. D. Stevens, I. Fridovich, Arch. Biochem. Biophys. 1994, 310, 341-346.

[33] R. H. Weiss, A. G. Flickinger, W. J. Rivers, M. M. Hardy, K. W. Aston, U. S. Ryan, D. P. Riley, J. Biol. Chem. 1993, 268, 2304923054.

[34] Y. Sawada, I. Yamazaki, Biochim. Biophys. Acta 1973, 327, 257-265.

[35] M. Baudry, S. Etienne, A. Bruce, M. Palucki, E. Jacobsen, B. Malfroy, Biochem. Biophys. Res. Commun. 1993, 192, 964-968.

[36] R. F. Pasternack, B. Halliwell, J. Am. Chem. Soc. 1979, 101, 1026-1031.

[37] J. Butler, W. H. Koppenol, E. Margoliash, J. Biol. Chem. 1982, 257, 10747-10750.

[38] Z.-R. Liao, X.-F. Zheng, B.-S. Luo, L.-R. Shen, D.-F. Li, H.L. Liu, W. Zhao, Polyhedron 2001, 20, 2813-2821.

[39] M. C. Rodriguez, Thesis, Université Paris-Sud, 1996, p. 249.

[40] M. C. Rodriguez, I. Morgenstern-Badarau, M. Cesario, J. Guilhem, B. Keita, L. Nadjo, Inorg. Chem. 1996, 35, 7804-7810.

[41] P. J. Gauuan, M. P. Trova, L. Gregor-Boros, S. B. Bocckino, J. D. Crapo, B. J. Day, Bioorg. Med. Chem. 2002, 10, 30133021.

[42] N. Kitajima, M. Osawa, N. Tamura, Y. Moro-Oka, T. Hirano, M. Hirobe, T. Nagano, Inorg. Chem. 1993, 32, 1879-1880.

[43] K. S. Yamaguchi, L. Spencer, D. T. Sawyer, FEBS Lett. 1986. $197,249-252$.

[44] E. A. Lewis, H. H. Khodr, R. C. Hider, J. R. Lindsay-Smith, P. H. Walton, J. Chem. Soc., Dalton Trans. 2004, 187-188.

[45] D. F. Xiang, C. Y. Duan, X. S. Tan, Q. W. Hang, W. X. Tang, J. Chem. Soc, Dalton Trans. 1998, 1201-1204.

[46] D. F. Xiang, X. S. Tan, Q. W. Hang, W. X. Tang, B.-M. Wu, T. C. W. Mak, Inorg. Chim. Acta 1998, 277, 21-25.

[47] D. Salvemini, Z.-Q. Wang, J. L. Zweier, A. Samouilov, H. Macarthur, T. P. Misko, M. G. Currie, S. Cuzzocrea, J. A. Sikorski, D. P. Riley, Science 1999, 286, 304-305.

[48] I. Spasojevic, I. Batinic-Haberle, R. D. Stevens, P. Hambright, A. N. Thorpe, J. Grodkowski, P. Neta, I. Fridovich, Inorg. Chem. 2001, 40, 726-739.

[49] R. Kachadourian, I. Batinic-Haberle, I. Fridovich, Inorg. Chem. 1999, 38, 391-396.

[50] K. W. Aston, N. Rath, A. Naik, U. Slomezynska, O. F. Schall, D. P. Riley, Inorg. Chem. 2001, 40, 1779-1789.

[51] H. Ukeda, S. Maeda, T. Ishii, M. Sawamura, Anal. Biochem. 1997, 251, 206-209.

[52] P. H. Walton, Department of Chemistry, University of York, personal communication.

[53] B. H. J. Bielski, Photochem. Photobiol. 1978, 28, 645-649.

[54] B. H. J. Bielski, D. E. Cabelli, R. L. Arudi, A. B. Ross, J. Phys. Chem. Ref. Data 1985, 14, 1041-1100. 
[55] B. H. J. Bielski, R. L. Arudi, Anal. Biochem. 1983, 133, 170178.

[56] D. E. Cabelli, B. H. J. Bielski, J. Phys. Chem. 1984, 88, 31113115.

[57] D. E. Cabelli, B. H. J. Bielski, J. Phys. Chem. 1984, 88, 62916294.

[58] A. Deroche, I. Morgenstern-Badarau, M. Cesario, J. Guilhem, B. Keita, L. Nadjo, C. Houée-Levin, J. Am. Chem. Soc. 1996, $118,4567-4573$.

[59] S. Goldstein, G. Czapski, D. Meyerstein, J. Am. Chem. Soc. $1990,112,6489-6492$.

[60] In ref. $1^{[1]}$, two IC50 values are reported for each complex. One value corresponds to that reported here. The other one, labeled specific IC50 or IC $50_{\text {spe }}$ was measured in the presence of an excess of ligand. This was done to estimate the effect of decoordination which could occur at a low concentration. For 3, IC5$0_{\text {spe }}=2.0 \pm 0.2 \mu \mathrm{mol} \mathrm{L}^{-1}\left(k_{\text {catspe }}=2.9 \pm 0.510^{6} \mathrm{~mol}^{-1} \mathrm{Ls}^{-1}\right)$ and for $4, I C 50_{\text {spe }}=1.7 \pm 0.2 \mu \mathrm{mol} \mathrm{L}^{-1} \quad\left(k_{\text {catspe }}=\right.$ $\left.3.4 \pm 0.410^{6} \mathrm{~mol}^{-1} \mathrm{Ls}^{-1}\right)$. These values are closer to the pulse radiolysis values.

[61] S. Durot, F. Lambert, J.-P. Renault, C. Policar, Eur. J. Inorg. Chem. 2005, 2789-2793.

[62] M. Tamura, Y. Urano, K. Kikuchi, T. Higuchi, M. Hirobe, T. Nagano, Chem. Pharm. Bull. 2000, 48, 1514-1518.
[63] S. Chen, J. F. Richardson, R. M. Buchanan, Inorg. Chem. 1994. $33,2376-2382$.

[64] K. J. Oberhausen, J. F. Richardson, R. M. Buchanan, W. Pierce, Polyhedron 1989, 8, 659-668.

[65] H. Geneste, M. Hesse, Tetrahedron 1996, 15, 15199.

[66] International Tables for X-ray Crystallography, Kluwer Academic Publishers, Dordrecht/Boston/London, 1995.

[67] A. Altomare, M. C. Burla, M. Camalli, G. L. Cascarano, C. Giacovazzo, A. Guagliardi, A. G. G. Moliterni, G. Polidori, R. Spagna, J. Appl. Crystallogr. 1999, 32, 115-119.

[68] G. M. Sheldrick, SHELXL-97, University of Göttingen, 1997.

[69] L. J. Farrugia, J. Appl. Crystallogr. 1999, 32, 837-838.

[70] M. Nardelli, J. Appl. Crystallogr. 1995, 28, 659.

[71] C. K. Johnson, M. N. Burnett, Report ORNL-6895, Oak Ridge National Laboratory, Oak Ridge, Tennessee, USA, 1996.

[72] A. L. Spek, PLATON, A Multipurpose Crystallographic Tool, University of Utrecht, 1999.

[73] K. M. Faulkner, S. I. Liochev. I. Fridovich. J. Biol. Chem. 1994. 269, 23471-23476. 